\title{
Pliensbachian-Toarcian ostracod biogeography in NW Europe: Evidence for water mass structure evolution
}

\author{
Carmen Arias* \\ Departamento de Paleontologia, Facultad de Ciencias Geologicas, Universidad Complutense de Madrid, \\ Jose Antonio Novais, 2; 28040-Madrid, Spain
}

\begin{abstract}
This paper examines the role played by palaeoceanographic and climatic conditions on the palaeobiogeography of the Pliensbachian Toarcian ostracods (Early Jurassic) in the European Epicontinental Sea (EES). The influence of the palaeogeography, ocean currents and sea level, temperature and salinity variations on ostracod abundance, diversity and migration patterns is reconstructed. Ostracod migration follows an anticlockwise circulation in the eastern side of the EES, with a leading northeast southwest movement, and the frequent arrival of Tethyan faunas into the central and western parts of the EES during the Pliensbachian. A three-fold classification of water masses based on salinity, temperature, lithological and fossil data is proposed. The repeated inflow of Tethyan ostracods into the EES ended by the earliest Toarcian. This ostracod event is related to the opening of the Hispanic Corridor and to the reorganization of the surface and deep circulations that may have generated a cold episode at the beginning of the Toarcian.
\end{abstract}

Keywords: Ostracod; Palaeobiogeography; Pliensbachian-Toarcian boundary; Water masses; Deep-water circulation; European Epicontinental Sea; Hispanic Corridor; Palaeoclimatology

\section{Introduction}

The aim of this paper is to describe the general pattern of ostracod migration between the European Epicontinental Sea (EES) and the Tethys Ocean (Fig. 1) during the Pliensbachian-Toarcian interval (Early Jurassic), showing their routes of migration and examining the significance of these movements in terms of palaeogeography, distribution of oceanic currents, heat fluxes, interchange of water masses, sea level variations and climate changes.

* Tel.: +34 91544 5459; fax: +34 3944849.

E-mail address: cariasf@geo.ucm.es.
Ostracods are a group of small crustaceans enclosed in a laterally compressed, bivalved calcareous carapace, with most of the species approximating to $1 \mathrm{~mm}$ in length (Schram, 1986). They live in all manner of aquatic habitats, reaching their highest diversity in carbonate environments in a mid-shelf warm tropical environment (Vannier et al., 1989). What is especially important is their almost ubiquitous occurrence in aquatic habitats of all kinds, combined with their precise environmental requirements. They can be excellent swimmers, but the vast majority live close to the sediment-water interface. Some authors believe (Van Morkhoven, 1962; Sandberg, 1964; McKenzie, 1973; Whatley, 1988; Babinot and Colin, 1992; Lethiers and Crasquin-Soleau, 1995) that ostracods might have a 


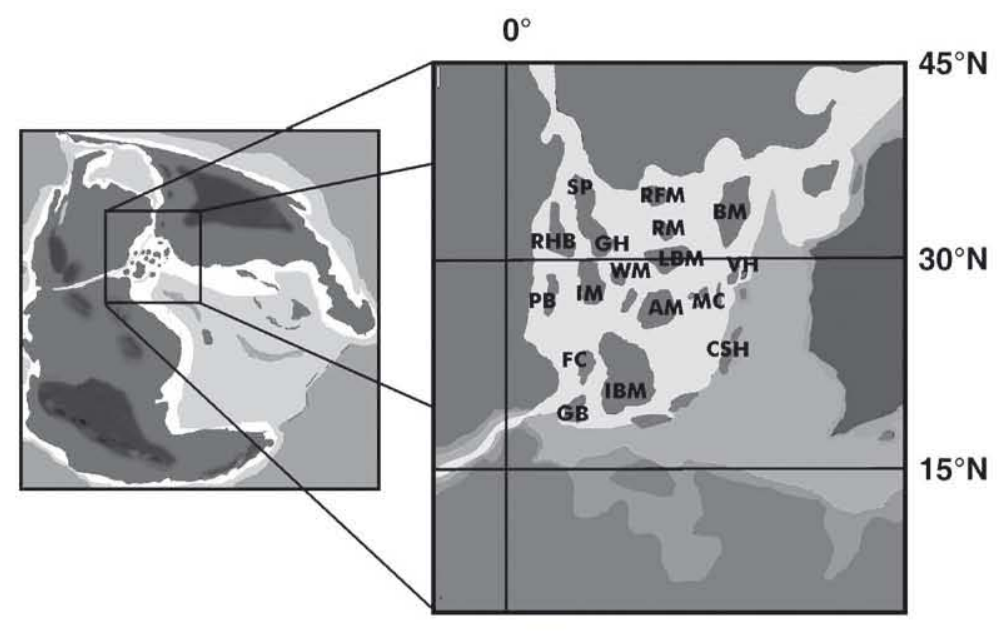

Fig. 1. Global Early Jurassic palaeogeography and Pliensbachian-Toarcian palaeogeography of the northwest European region (modified from Ziegler, 1988, 1990, 1992; Bassoullet et al., 1992; Ziegler et al., 2001; Scotese, 2002). Emergent areas: AM: Armonican Massif; BM: Bohemian Massif; C-S H Corsica-Sardinia High; FC: Flemish Cap; GB: Grand Bank; GH: Grampian High; IBM: Iberian Meseta; IM: Irish Massif; LBM: London-Brabant Massif; MC: Massif Central; PB: Porcupine Bank; RFM: Ringk?bing-Fyn-High; RHB: Rockall-Hatton Bank; RM: Rhenish Massif; SP: Shetland Platform; VH: Vindelecian High; and WH: Welsh Massif.

limited trans-oceanic migration capacity (eggs, pre-adult and adult stages would be passively dispersed by means of wind, birds, fish, drifting algae or ocean currents). Since the majority of present day ostracod species have a high degree of ecological flexibility and tolerance, they should have a high ability to successfully invade new environments. However, it appears that migration from deep to shallow water seems unlikely to have occurred. Thus, a careful analysis of ostracod assemblages can be extremely useful as palaeotemperature and palaeosalinity indicators, and they may also provide valuable data on palaeobathymetry (water masses and deep-water circulation).

\section{Materials and methods}

The data used in this analysis are based on 210 Pliensbachian and Early Toarcian ostracod species (Table 1) taken from 199 published papers. Since the number of individual localities is large, the sites were grouped into 15 large geographical areas: C: Grand Banks, Canada; CI: the Cordillera Ibérica, Spain; DK: Danish Embayment, Denmark; FB: the Fastnet and North Celtic Basins; GB: British basins; It: Italy; M: Morocco; NEG: Northeast Germany; NWG: Northwest Germany; PB: the Paris Basin, France; Q: Quercy, France; P: the Lusitanian Basin, Portugal; SWG: Southwest Germany; S: Skøne, Sweden; and Sz: Switzerland (Fig. 2).

Only illustrated taxa have been considered, and the methodology followed is based on the individual palaeo- geographical analysis of each ostracod species. Each species was plotted on a palaeogeographical map, using one map for each time period. All of the species placed together in each palaeogeographical reconstruction allowed the drawing of a general pattern of migration for each temporal interval. Although faunal interchange routes have been mainly deduced from the study of Early Jurassic ostracods, several other invertebrate fossil groups, including ammonites, bivalves and brachiopods have also been considered.

\section{Geological setting}

The world palaeogeography of $210-179$ million years BP was characterized by the presence of a large landmass (the Pangaea) centered over the equator, surrounded by a huge worldwide ocean (the Panthalassa Ocean) and with a wedge-shaped ocean running into the eastern margin (the Tethys Ocean). Pangaea split into two continents (Laurasia and Gondwana) at the beginning of the Late Triassic, with an epicontinental sea formed between $5^{\circ} \mathrm{N}$ and $25^{\circ} \mathrm{S}$ of the two landmasses. This is designated the European Epicontinental Sea (EES) (Figs. 1 and 2).

The evolution of the Early Jurassic EES was strongly influenced by the evolution of the Central Pangaea and by sea level variations. This coupled action allowed the development of new seaways and barriers among the different basins through the epicontinental sea (Vail et al., 1977; Hallam, 1978; Kutzbach et al., 1990). The Late Triassic marked the end of the Pangaea 
Table 1

List of Pliensbachian and Toarcian ostracod species mentioned in the text

Ostracod species

Acrocythere gassumensis (Michelsen, 1975)

Acrocythere oeresundensis (Michelsen, 1975)

Acrocythere troesteri (Riegraf, 1984)

Ambigocythere concentricostata (Herrig, 1985)

Aphelocythere kuhni (Triebel and Klingler, 1969)

Bairdia kempfi (Ainsworth, 1989)

Bairdia clio (Bizon, 1960)

Bairdia crassa (Drexler, 1958)

Bairdia donzei (Herrig, 1979a,b)

Bairdia guttulae (Herrig, 1979a,b)

Bairdia hahni (Lord and Moorley, 1974)

Bairdia michelseni (Herrig, 1979a,b)

Bairdia molesta (Apostolescu, 1959)

Bairdia ohmerti (Knitter, 1983)

Bairdia praehilda (Herrig, 1979a,b)

Bairdia rostrata (Issler, 1908)

Bairdia thuringica (Knitter, 1983)

Bairdia? sp. A (Ainsworth, 1986a,b)

Bairdia sp. A (Ohm, 1986)

Bairdia eirensis (Ainsworth, 1986a,b)

Bairdiacypris anisica brevis (Herrig, 1979a,b)

Bairdiacypris dorisae (Knitter, 1983)

Bairdiacypris rectangularis (Ainsworth, 1986a,b)

Bairdiacypris triangularis (Ainsworth, 1986a,b)

Bairdiacypris triasica postera (Herrig, 1979a,b)

Bythocypris fabaeformis (Drexler, 1958)

Bairdiacypris tumida (Ainsworth, 1987)

Cardobairdia fastnetensis (Ainsworth, 1987)

Cardobairdia liassica (Drexler, 1958)

Cardobairdia toarcensis (Ainsworth, 1986a,b)

Cardobairdia Nr. 103 (Klingler, 1962)

Cardobairdia sp. A (Ainsworth, 1987)

Cardobairdia sp. K (Apostolescu, 1959)

Cristacythere betzi (Klingler and Neuweiler, 1959)

Cythere? terquemiana (Jones, 1872)

Cytherella demiexensis (Ainsworth, 1989)

Cytherella lindseyensis (Lord, 1974a,b,c)

Cytherella praecadomensis (Knitter and Riegraf, 1984)

Cytherella toarcensis (Bizon, 1960)

Cytherelloidea anningi (Lord, 1974a,b,c)

Cytherelloidea cadomensis (Bizon, 1960)

Cytherelloidea drexlerae (Field, 1966)

Cytheropteron alafastigatum (Fischer, 1962)

Cytheropteron byfieldensis (Boomer and Bodergat, 1992)

Cytheropteron cavatum (Michelsen, 1975)

Cytheropteron diversum (Herrig, 1969a, b)

Cytheropteron foveolatum (Michelsen, 1975)

Cytheropteron? sp. A (Riegraf, 1985)

Cytheropteron sp. B (Riegraf, 1985)

Ektyphocythere acuminata (Riegraf, 1984)

Ektyphocythere ambo (Boomer, 1988)

Ektyphocythere anterocosta (Boomer, 1988)

Ektyphocythere bucki (Bizon, 1960)

Ektyphocythere champeau (Bizon, 1960)

Ektyphocythere debilis (Bate and Coleman, 1975)

Ektyphocythere dharennsourensis (Boutakiout et al., 1982)

Ektyphocythere intrepida (Bate and Coleman, 1975)
Table 1 (continted)

Ostracod species

Ektyphocythere knitteri (Riegraf, 1984)

Ektyphocythere lanceolata (Boomer, 1988)

Ektyphocythere luxuriosa (Apostolescu, 1959)

Ektyphocythere multicostata (Klingler and Neuweiler, 1959)

Ektyphocythere neumannae (Maupin, 1978)

Ektyphocythere quadrata (Boomer and Lord, 1988)

Ektyphocythere vitilis furcata (Wienholz, 1958)

Ektyphocythere aff. Ektyphocythere vitiosa (Apostolescu, 1959)

Ektyphocythere vulgaris (Klingler and Neuweiler, 1959)

Eucytherura angulocostata (Knitter, 1983)

Eucytherura liassica (Bate and Coleman, 1975)

Eucytherura tatei (Ainsworth, 1986a,b)

Eucytherura tricostata (Michelsen, 1975)

Eucytherura sp. (Riegraf, 1985)

Fabalacypris symmetrica (Herrig, 1979a,b)

Gammacythere ubiquita (Malz and Lord, 1976)

Gramannella apostolescui (Gramann, 1963)

Gramannella laevigata (Michelsen, 1975)

Gramannella tatei (Gramann, 1963)

Gramannicythere aubachensis (Riegraf, 1984)

Gramannicythere bachi (Herrig, 1982a,b)

Gramannicythere coniuncta (Herrig, 1982a,b)

Gramannicythere sp. (Malz and Nagy, 1989)

Hermiella ambo (Lord and Moorley, 1974)

Hermiella cincta (Malz, 1975)

Hermiella circumvallata (Dreyer, 1967)

Hermiella comesMalz, 1975

Hermiella hyblea (Barbieri, 1964)

H. intercedens (Dreyer, 1967)

Hermiella klingleri (Malz, 1975)

Hutsonia decorata (Apostolescu et al., 1961)

Hutsonia aff. Hutsonia decorata (Apostolescu et al., 1961)

Infracytheropteron groissi (Knitter, 1983)

Infracytheropteron gwashense (Bate and Coleman, 1975)

Infracytheropteron pulchellum (Michelsen, 1975)

Infracytheropteron rarum (Knitter, 1983)

Infracytheropteron riegrafi (Riegraf, 1985)

Infracytheropteron supraliasicum (Herrig, 1981a,b,c)

Isobythocypris cylindrica (Herrig, 1979a,b)

Isobythocypris dorsoconversa Ainsworth, 1986a,b

Isobythocypris fabaeformis (Drexler, 1958)

Isobythocypris ovalis (Bate and Coleman, 1975)

Isobythocypris pliensbachiensis (Ainsworth, 1986a,b)

Isobythocypris tatei (Coryell, 1963)

Isobythocypris unispinata (Apostolescu, 1959)

Kinkelinella costata (Knitter, 1984)

Kinkelinella fischeri (Malz, 1966)

Kinkelinella mandelstami (Wienholz, 1958)

Kinkelinella persica (Bate and Coleman, 1975)

Kinkelinella procera (Herrig, 1985)

Kinkelinella sermoisensis (Apostolescu, 1959)

Kinkelinella tenuicostata (Martin, 1960)

Klinglerella elongata (Michelsen, 1975)

Klinglerella foveolata (Michelsen, 1975)

Klinglerella herrigi (Ainsworth, 1989)

Klinglerella intermedia (Klingler and Neuweiler, 1959)

Klinglerella katsloesensis (Sivhed 1980)

Klinglerella lacunosa (Ainsworth, 1989)

Klinglerella moorei (Brady, 1872) 
Table 1 (continued)

Ostracod species

Klinglerella variabilis (Klingler and Neuweiler, 1959)

Ledahia conviniens (Herrig, 1980)

Ledahia septenaria (Grïndel, 1964)

Liasina lanceolata (Apostolescu, 1959)

Liasina? vestibulifera (Gramann, 1962)

Liasina cylindrica (Ainsworth, 1986a, b)

Monoceratina amlingstadtensis (Triebel and Bartenstein, 1938)

Monoceratina mesoliassica (Triebel and Bartenstein, 1938)

Monoceratina michelseni (Riegraf, 1984)

Monoceratina seebergensis (Triebel and Bartenstein, 1938)

Monoceratina stimulea (Schwager, 1866)

Monoceratina striata (Triebel and Bartenstein, 1938)

Monoceratina ungulina (Triebel and Bartenstein, 1938)

Nanacythere (D.) firma (Herrig, 1969a,b)

Nanacythere (D.) fissicosta (Herrig, 1969a,b)

Nanacythere (G.) minor (Michelsen, 1975)

Nanacythere ( $N$.) simplex (Herrig, 1969a,b)

Nanacythere persicaeformis (Riegraf, 1984)

Ogmoconcha amalthei amalthei (Quenstedt, 1967)

Ogmoconcha amalthei rotunda (Dreyer, 1967)

Ogmoconcha contractula (Triebel, 1941)

Ogmoconcha convexa (Boomer, 1991)

Ogmoconcha dentata (Issler, 1908)

Ogmoconcha eocontractula (Park, 1984)

Ogmoconchella adenticulata (Pietrzenuk, 1961)

Ogmoconchella aequalis (Herrig, 1969a,b)

Ogmoconchella aspinata (Drexler, 1958)

Ogmoconchella danica (Michelsen, 1975)

Ogmoconchella impressa (Malz, 1975)

Ogmoconchella michelseni (Michelsen, 1975)

Ogmoconchella mouhersensis (Apostolescu, 1959)

Ogmoconchella secunda (Herrig, 1981a,b,c)

Ogmoconchella propinqua (Malz, 1971)

Ogmoconchella sp. A (Lord, 1974a,b,c)

Ogmoconchella sp. B (Apostolescu, 1959)

Olygocythereis? mochrarensis (Boomer, 1991)

Paracypris liassica (Bate and Coleman, 1975)

Paracypris redcarensis (Blake, 1876)

Paracypris sp. (Cubaynes, 1986)

Paracypris sp. 1 (Exton, 1979)

Paracypris sp. 2 (Exton, 1979)

Paracypris sp. A (Riegraf, 1985)

Paracypris sp. C (Ainsworth, 1986a,b)

Pleurifera harpa harpa (Klingler and Neuweiler, 1959)

Pleurifera harpa harpoidea (Gramann, 1962)

Pleurifera vermiculata (Apostolescu, 1959)

Polycope minor (Michelsen, 1975)

Polycope pelta (Fischer, 1961a)

Polycope plumhoffi (Bate and Coleman, 1975)

Polycope cerasia (Blake, 1876)

Polycope cincinnata (Apostolescu, 1959)

Polycope decorata (Apostolescu, 1959)

Polycope tenuireticulata (Herrig, 1981a,b,c)

Praeschuleridea arguta (Ainsworth, 1986a,b)

Praeschuleridea aspera (Knitter, 1983)

Praeschuleridea bernierensis (Apostolescu, 1959)

Praeschuleridea costata (Ainsworth, 1986a,b)

Praeschuleridea ellipsoidea (Ainsworth, 1986a,b)

Praeschuleridea gallemannica (Malz, 1966)
Table 1 (continued)

Ostracod species

Praeschuleridea levita (Ainsworth, 1986a,b)

Praeschuleridea magnycourtensis (Apostolescu, 1959)

Praeschuleridea pseudokinkelinella (Bate and Coleman, 1975)

Praeschuleridea punctulata (Plumhoff, 1963)

Praeschuleridea reticulata (Ainsworth, 1986a,b)

Praeschuleridea ventriosa (Plumhoff, 1963)

Praeschuleridea whatleyi (Ainsworth, 1986a,b)

Procytheridea? jardensis (Maupin, 1978)

Procytherura celtica (Ainsworth, 1986a,b)

Procytherura euglyphea (Ainsworth, 1986a,b)

Procytherura hastata (Bate and Coleman, 1975)

Procytherura mediocastata (Bate and Coleman, 1975)

Procytherura multicostata (Ainsworth, 1986a,b)

Procytherura suebica (Herrig and Richter, 1990)

Procytherura werneri (Riegraf, 1984)

Procytherura? exquisita (Ainsworth, 1986a,b)

Procytherura? liassica (Ainsworth, 1986a,b)

Progonoidea reticulate (Klingler and Neuweiler, 1959)

Pseudohealdia etaulensis (Apostolescu, 1959)

Pseudohealdia gruendeli (Malz, 1971)

Pseudohealdia transversa (Gründel, 1970)

Pseudohealdia grodidieri (Viaud, 1963)

Pseudohealdia pseudoespina (Herrig, 1969a,b)

Pseudohealdia pseudohealdidae (Gründel, 1964)

Pseudohealdia truncata (Malz, 1971)

Pseudomacrocypris subaequalis (Michelsen, 1975)

Pseudomacrocypris? sp. A (Ainsworth, 1986a,b)

Pseudomacrocypris subtriangularis (Michelsen, 1975)

Trachycythere angusta (Triebel and Klingler, 1969)

Trachycythere horrida (Triebel and Klingler, 1969)

Trachycythere tubulosa seratina (Triebel and Klingler, 1969)

Trachycythere tubulosa tubulosa (Triebel and Klingler, 1969)

Trachycythere verrucosa (Triebel and Klingler, 1969)

Triassocythere multiestriata (Michelsen, 1975)

Triassocythere? sp. 4135 (Michelsen, 1975)

supercontinent. Its break-up commenced with the southward propagation of the Norwegian-Greenland rift into the Central Atlantic area, and the gradual westward propagation of the Tethys rift (McHone, 1996, Marzoli et al., 1999; McHone, 2000; Bartolini and Larson, 2001; Mchone, 2002; Hames et al., 2002). By the Late Triassic, the area between both the continents, along the present European continent, was the site of a shallow carbonate platform that became a stable epicontinental sea with restricted basins among an archipelago of islands (Ziegler, 1988, 1992). Another consequence of the evolution of this rifting system was the development of a mosaic of structural highs and lows in Western Tethys, subsequently covered by small carbonate platforms, from the Iberian Massif through to the Apulia Block (Laubscher and Bernoulli, 1977; Bassoullet et al., 1992; Stampfli et al., 1991, 1998; Ziegler et al., 2001). 


\section{Palaeobiogeographical analysis}

\subsection{Early Pliensbachian}

The analysis of Early Pliensbachian ostracod palaeobiogeography exhibits two main characteristics: a clear southward movement of the EES faunas, and the constant influx of Tethyan faunas into the central and western parts of the EES during the Early and middle Early Pliensbachian (Fig. 3a, A and B). Ostracods and other fossil groups suggest several routes, which Tethyan forms could have followed (the Balcony Mounts, the North Austrian Alps, the Sub-Briaçonnais and the Upper Austroalpine or the Bohemian Massif) through the southern EES (Faugeres and Mouterde, 1980; Dommergues, 1982; Enay and Mangold, 1982; Cariou et al., 1985; Dommergues, 1987; Dommergues and Meister, 1990, 1991, 1992; Meister and Stampfly, 2000; Arias and Whatley, 2004).

The existence of these interchange areas is a consequence of the plate-tectonic history of this area. Hettangian carbonate platforms (High Middle Atlas, Sahara Atlas, Moroccan Massif, Sub-Betic and Apennines) began to break-up at the end of Early Sinemurian. From the Late Sinemurian to the Early Pliensbachian, the marine transgression extended along these platforms with new seaways being created (Dommergues, 1979; Enay, 1980; Dommergues, 1982; Alméras and Moulan, 1982; Alméras and Elmi, 1987, 1993; Alméras and Faure, 2000).

In the Early Pliensbachian, the pattern of ostracod distribution along the eastern coast of the EES illustrates the long-standing entrance of Tethyan taxa, which expanded from the southwestern German to northern German and Danish basins, then rotating back around to the Iberian basins. This movement follows an anticlockwise circulation throughout the eastern EES. During much of the Early Pliensbachian, the ostracod fauna (e.g. Bairdia donzei, Bairdia guttulae, Bairdia michelseni, Bairdia molesta, Bairdia rostrasta, Hermiella intercedens, Ogmoconchella aff. $O$. aspinata) moved from the northeastern to southwestern areas of the EES around the London-Brabant and the Armorican Massif, through the Western Approaches Trough and the Bay of Biscay to the Iberian basins. Direct communication between the Paris Basin and the Quercy area is not apparent, possibly due to the closure of the "Seuil du Poitou", a shallow zone joining the Armorican to the Central Massifs and separating the Aquitaine and Paris Basins (Gabilly, 1976).

When the ostracod results are compared with those obtained from other fossil groups, such as ammonites, we see a close agreement. Early Pliensbachian ammonites (Liparoceratidae, Acanthopleuroceratidae and Dacty- lioceratidae) extended northward from the Briaconnais area, Burgundy to the British basins and subsequently to the Cordillera Ibérica, Spain, reaching even Greenland (Dommergues, 1982; Phelps, 1985; Dommergues, 1987; Dommergues and Meister, 1992; Cariou and Hantzpergue, 1997; Dommergues et al., 1997).

\subsection{Late Pliensbachian}

During the Late Pliensbachian, Tethyan ostracod faunas continued to enter into the EES, especially through its southern and western margins. At the beginning of the Late Pliensbachian (Fig. 3a, C), the continuous southwards expansion of ostracod faunas from the northern parts of the EES to the Bay of Biscay and the Iberian basins is observed in the movements of several species, such as Cytherella toarcensis, Ektyphocythere quadrata, Hermiella ambo, Hermiella comes, Ledahia septenaria, Liasina vestibulifera, Ogmoconcha amalthei and Pleurifera harpa. The mid Early Pliensbachian represents the maximum Tethyan influence in the EES. But by the latest Early Pliensbachian (Fig. 3a, D) this northward expansion had ended.

It is remarkable that in the latest Pliensbachian many species that originated in the northern German basins did not appear in the British and Spanish basins until later. This interruption may have been due to the presence of some kind of barrier along the southern margin of the London-Brabant Massif that kept the British basins in isolation. Physical barriers, such as the Morton-in-the-Marsh and Market-Weighton highs, may have served as temporary barriers to faunal movement between northern German and the southern British basins (Donovan, 1967; Mégnien, 1980; Dommergues, 1982; Enay and Mangold, 1982; Meister and Stampfly, 2000; Arias and Whatley, 2004).

At the end of the Late Pliensbachian (Fig. 3a, D), the continuing transgression totally connected the Paris Basin with the southern British and German basins. This connection can be observed in the study of the movement of the large cytheroids (Ektyphocythere aff E. vitiosa, Gramannella apostolescui, Pseudohealdia pseudohealdidae, Trachycythere tubulosa tubulosa and Trachycythere verrucosa) that dominated ostracod assemblages at the end of the Pliensbachian. The composition and abundance of Spanish ostracods was quite similar to that of the French area, but they have less similarity with the coeval assemblages from British, German and Danish areas (Arias and Lord, 1999a,b).

Brachiopods offer supplementary confirmation. The analysis of the distribution of Lower Jurassic brachiopod faunas (Ager, 1956, 1960, 1971, 1973) allowed the 


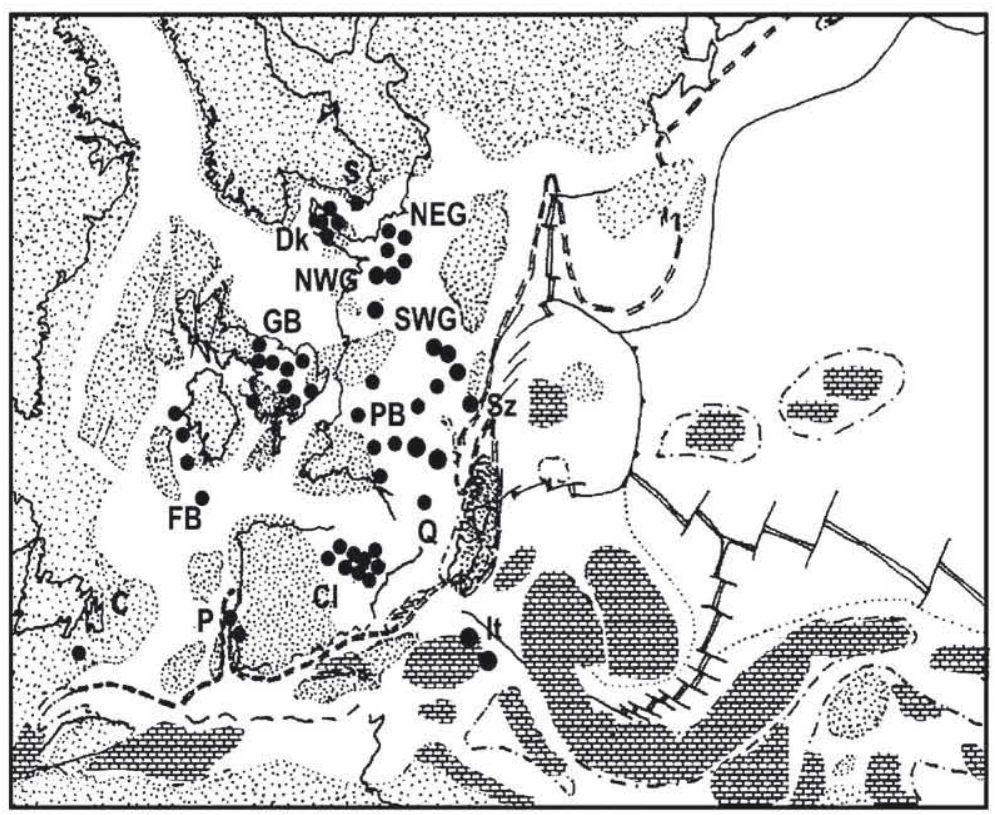

Fig. 2. Palaeogeographic position of the selected localities during the Toarcian (after Ziegler, 1988; Bassoullet et al., 1992). (1) Northeastern Germany (NEG): Dobbertin and Eisenach (Pietrzenuk, 1961), Brandenburg (Dreyer, 1967); Greifswald (Herrig, 1969a,b); Thüringen (Herrig, 1979a,b; 1980; 1981 a,b,c; 1982a,b); (2) Northwestern Germany (NWG): Niedersachten (Triebel and Bartenstein, 1938); Hannover (Triebel and Klingler, 1959); Weseker Sattel (Gramann, 1963); Niedersachten (Malz, 1971); Empelde (Ohm, 1986); (3) Southwestern Germany (SWG): Baden-Württemberg (Knauff, 1954; Klinger and Neuweiler, 1959; Fischer, 1961a,b,c; Malz, 1961, 1966, 1975; Klingler, 1962; Lord and Morley, 1974; Urlichs, 1977; Knitter, 1983, 1984; Knitter and Ohmert, 1983; Knitter and Riegraf, 1984; Harloff, 1993); Kalk-Alpen Bayern and North Tyrol (Harloff and Jäger, 1994); (4) Grand Banks, Newfoundland Canada (C): (Exton and Gradstein, 1984); (5) Cordillera Ibérica, Spain (CI): (Arias, 1995, 1997, 2000; Arias and Lord, 1999a,b); (6) Celtic Sea-Fastnet Basin-Porcupine (FB): (Ainsworth, 1986a,b, 1987, 1989, 1990; Ainsworth and Horton, 1987; Ainsworth et al., 1987); (7) Danish Embayment, Denmark (Dk): (Michelsen, 1975); (8) Skane, Southern Sweden (S): (Sivhed, 1980); (9) The Paris Basin, France (PB): (Apostolescu, 1959, 1961; Apostolescu et al., 1961; Bizon and Oertli, 1961; Cousin and Apostolescu, 1961; Champeau, 1961; Magné et al., 1961; Magné and Malmoustier, 1961; Oertli and Grosdidier, 1961; Magné and Obert, 1966; Maupin, 1978; Bodergat et al., 1985, 1991; Dépêche, 1985; Donze, 1985; Riegraf, 1985; Bodergat and Donze, 1988); (10) Quercy, southern France (Q): (Cubaynes and Ruget, 1985; Cubaynes, 1986; Bodergat et al., 1991, 1998; Andreu et al., 1998); (11) Great Britain (GB): Central and southern England (Lord, 1971a,b, 1972, 1974a,b,c, 1978, 1988); Empingham and Upwood (Bate and Coleman, 1975); Ilminster (Boomer, 1991); Dorset and Isle of Wight (Lord and Bown, 1987); Mochras, Wales (Boomer, 1992); (12) Central Italy (It): Strettura (Lord, 1978, 1988); Umbria (Arias, 1993); (13) Zambujal, Portugal (P): (Exton, 1979; Exton and Gradstein, 1984; Boomer et al., 1998) and (14) NW Switzerland (Sz): (Richter, 1987; Tröster, 1987).

recognition of a series of belts throughout the EES. The intermediate belt, regarded as Tethyan facies (characterized by the scarce occurrence of axiniform rhynchonellids, and some species of Terebratula) would have spread throughout the southern part of Germany, France and southwestern England. Around it, the outermost belt would include northeast England, from southeast Germany to the Carpathian area to the east; and Normandy and Causes (France), the Iberian Peninsula and north Morocco to the west. This belt is characterized by the presence of Tetrarhynchia, Gibbirhynchia and Lobothyris, dentate zeillerids and ribbed spiriferids, and reflects the initial northward extension followed by the westward extension of the European Epicontinental faunas. The palaeobiogeography of the latest Pliensbachian bivalves (Liu et al., 1998) reveals how problematical the communication between the northern and central part of the EES became. Two bivalve provinces are recognized within the Proto-Atlantic: the Boreal Bivalve Province in the north (England, northwestern Germany and Denmark) and the Southern Transitional Province (Spain, France and Portugal). The former province is assigned to the Boreal Faunal Realm, the latter one to the Tethyan Faunal Realm.

Ammonites give us additional evidence on the ocean surface current pattern with the migration of some important taxon, such as the northward migration of Amaltheidae into the regions previously dominated by Harpoceratinae, extending into the southwestern German, French and central British basins, as well as the North Atlantic strait, the periarctic American coast and the northern coast of Siberia (Enay and Mangold, 1982) during the middle-Late Pliensbachian. This movement was accompanied by a southwestward expansion to the 
southern parts of the EES in the Late Pliensbachian (Dommergues and Mouterde, 1980; Enay and Mangold, 1982; Dommergues and Mouterde, 1987; Dommergues, 1987; Andreu et al, 1998; Meister and Stampfly, 2000).

The other route of migration of Tethyan ostracod and other invertebrate groups, the Iberian-Moorish Strait, took place around the western corner of the EES, from North Africa to the Iberian Peninsula and the British basins by the middle Early Pliensbachian (Elmi et al., 1974; Faugeres and Mouterde, 1980; Elmi et al., 1982; Dommergues, 1982; Enay and Mangold, 1982; Thierry, 1988; Arias, 2000). Ostracod species, such as Ektyphocythere dharennsourensis, corroborate the existence of this very active migration route by the Late Pliensbachian-Early Toarcian (Arias, 2000). The ammonites and brachiopods also indicate the existence of this route (e.g. the migration of sulcate terebratullids from the Rift area and western part of the Cordillera Bética through western Portugal to southwestern England and Normandy by the Late Pliensbachian (Ager, 1956). Elmi et al. (1982) described the migration of Moroccan costate terebratullids to Portugal, Spain, France and Great Britain (Ager and Walley, 1977; Elmi et al., 1982). Other examples include the spatial distribution of the ammonite genus Hildoceratidae, described in the Lusitanian Basin, the Cordillera Ibérica, Normandy and southern England, or the occurrence of Mediterranean ammonites Reynesocoeloceras and Bouliceras (described originally from Madagascar, Kenya, Somalia, Arabia, Morocco) in Portugal and Spain (Mouterde, 1953; Mouterde et al., 1979; Dommergues and Mouterde, 1987; Goy and Martinez, 1990). Hallam (1971) described the close similarity between Pliensbachian bivalve assemblages from Morocco, Spain, England and Greenland.

\subsection{Early Toarcian}

In terms of the ostracod fauna migration, the earliest Toarcian (Fig. 3b, E) maintains a similar distribution pattern to the Late Pliensbachian, with a southward expansion of faunas from the northern part of the EES to the Iberian basins, with an anticlockwise circulation in the central parts of the EES. This pattern can be observed in the movement of several ostracod species, such as $B$. molesta, Ektyphocythere bucki, Ektyphocythere neumannae, $G$. apostolescui, Kinkelinella tenuicostata, $L$. septenaria, $L$. vestibulifera, Monoceratina striata, Monoceratina ungulina, Polycope cincinnata and T. tubulosa seratina. Only the presence of some kind of barrier may have modified this general model.
The distribution of a number of ostracod species $(B$. donzei, $C$. toarcensis, Cytheropteron byfieldensis, Isobythocypris tatei, Kinkelinella sermoisensis, E. bucki, Ektyphocythere champeau, E. aff E. vitiosa, L. septenaria, Monoceratina stimulea and T. tubulosa) indicates the opening of the connection between the Aquitaine Basin and the Cordillera Ibérica area at the commencement of the Toarcian. This new route closes off one large anticlockwise gyre in central EES.

Another proposed route for the entrance of the Tethyan fauna was through the Betic area. Ammonite assemblages from the Cordillera Ibérica clearly belong to the Euroboreal realm, while the Betic assemblages show faunal affinities with those described from the Mediterranean area (Braga et al., 1982; Goy et al., 1988; Gómez and Goy, 2002). Therefore, during the Pliensbachian and Toarcian the faunal evidence suggests some type of barrier (Ruiz-Ortiz et al., 2004) between both Cordilleras. Vera (1998) shows, in his evolutionary model of the southern Iberian Continental palaeomargin, that during the Pliensbachian-Toarcian began a phase of intercontinental rifting which created a mosaic of structural highs and lows in the Sub-Betic area, while the pre-Betic area remained as a shallow zone. Elmi et al. (1982) and Vera (1998) suggested that the southern Iberian palaeomargin acted as a barrier for the entrance of Tethyan faunas (Elmi et al., 1982; Cariou et al., 1985; Alméras and Elmi, 1987; Dommergues, 1987).

During the falciferum zone (Early Toarcian) an important change is detected in the circulation model (Fig. 3b, F). The connection between the central and western European basins was weaker than during earlier periods, while analysis of the ostracod distribution distinguishes an interruption of the communication between British, French and German basins. The communication between the French and Spanish basins, however, remained active. This observation is supported by the migration of several ostracod species, such as Bairdiacypris dorisae, C. toarcensis, E. bucki, Ektyphocythere anterocosta, Infracytheropteron gwashense, $K$. tenuicostata and $M$. striata.

Preservational bias and incompleteness of the fossil record in the central basins of the EES have been repeatedly related to early phases of black shale deposition (e.g. the Jet Rock in Great Britain, Posidonschiefer in Germany and Switzerland or Schistes Cartons in France), occurring principally in the falciferum zone, although locally extending into the tenuicostatum zone (Hallam, 1981; Riegraf, 1984; Riegraf et al., 1984; Reigraf, 1985; Jenkyns, 1985; Hallam, 1987; Espitalié et al., 1987; Fleet et al., 1987; Jenkys, 1988; Ziegler, 1988, 1991). These shales have been 
explained in terms of restricted circulation, salinity stratification, slow sedimentation rates, anoxic bottom waters and low productivity; or even the reverse, high sedimentation rates and high productivity, possible upwelling (Parrish and Curtis, 1982; Wignall and Meyers, 1990; Tyson and Pearson, 1991; Wignall and Hallam, 1991; Jenkyns and Clayton, 1997; Schmid-Röhl et al., 2002).

The deposition of the Toarcian black shales is also reflected in another fossil group, the brachiopods, with an important crisis (Choffat, 1947; Goy, 1974; GarciaJoral and Goy, 1984; Goy et al., 1984; Alméras and Elmi, 1993; Alméras and Faure, 2000) marked by the disappearance of spiriferids and the development of very particular faunas (ubiquitous forms belonging to the "Spanish facies" described from the French Provence to the Atlas Basin).

The reduction in communication among the different basins was only transitory, as a re-opening of the seaways between the central and western European basins took place in the bifrons zone. Ostracod species, such as, Cytherella praecadomensis, C. toarcensis, Cytheropteron alafastigatum, C. byfieldensis, E. bucki, E. champeau, Ektyphocythere debilis, Eucytherura angulocostata, Eucytherura tricostata, Kinkelinella costata, K. fisheri, $K$.

\section{a}

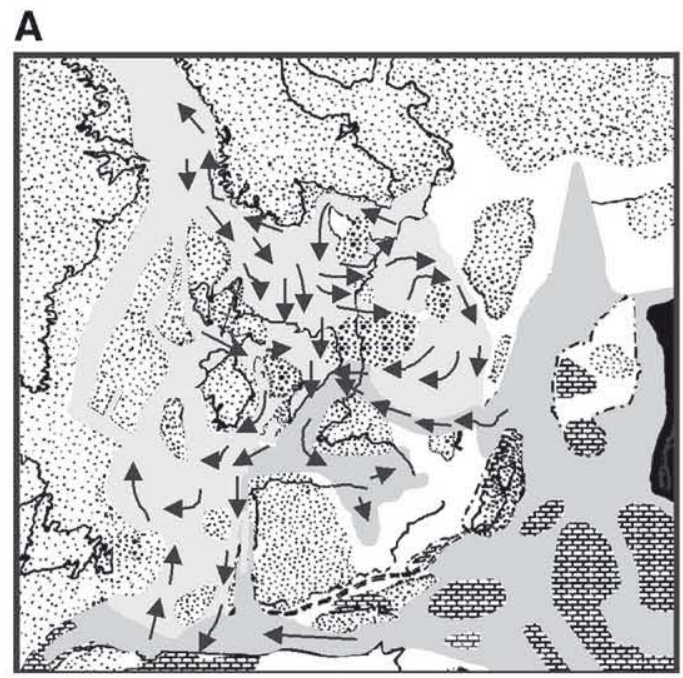

B

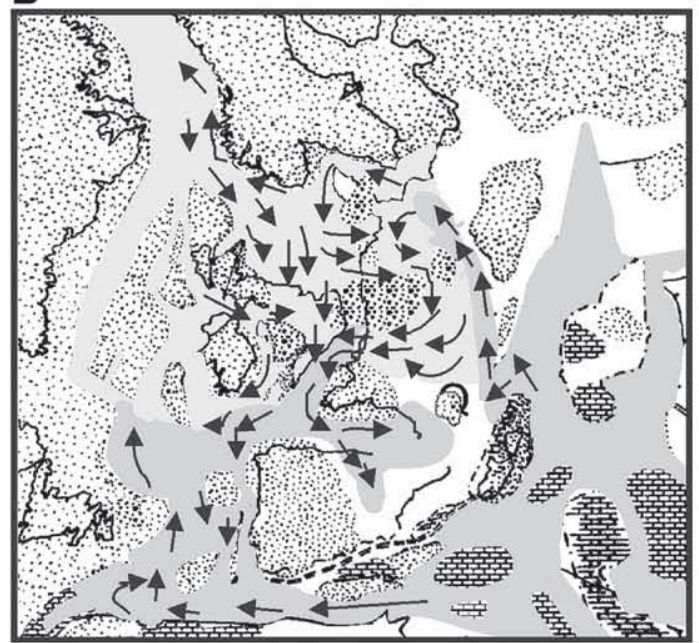

C

D
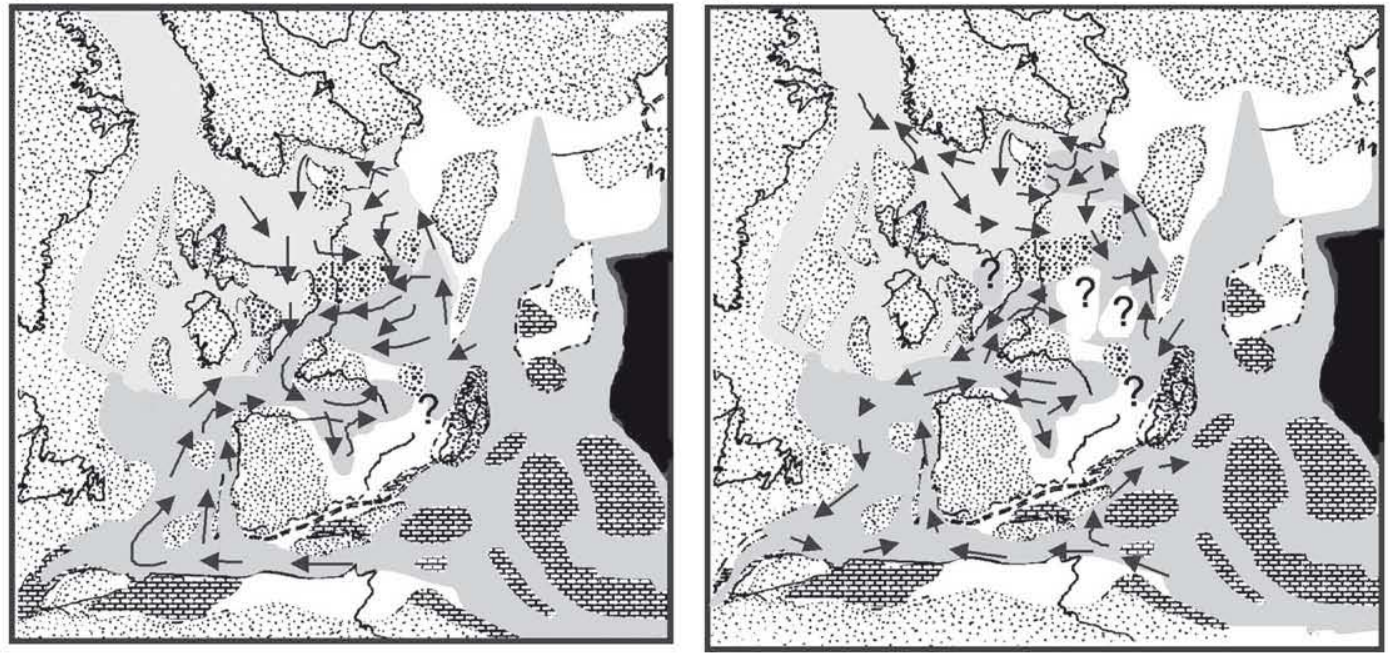

Fig. 3. Ostracod migration routes. (a) (A) Early Pliensbachian (jamesoni zone); (B) Early Pliensbachian (ibex and davoei zones); (C) Late Pliensbachian (margaritatus zone); (D) Late Pliensbachian (spinatum zone); and (b) (E) Pliensbachian-Toarcian (tenuicostatum zone); (F) Early Toarcian (falciferum zone); (G) Early Toarcian (bifrons zone). Black arrows show the direction of ostracod migration. 
b

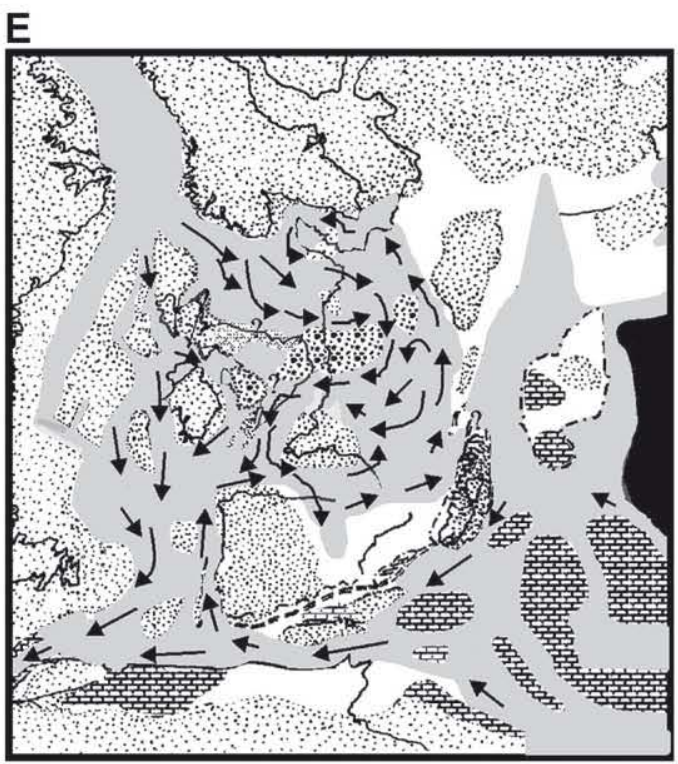

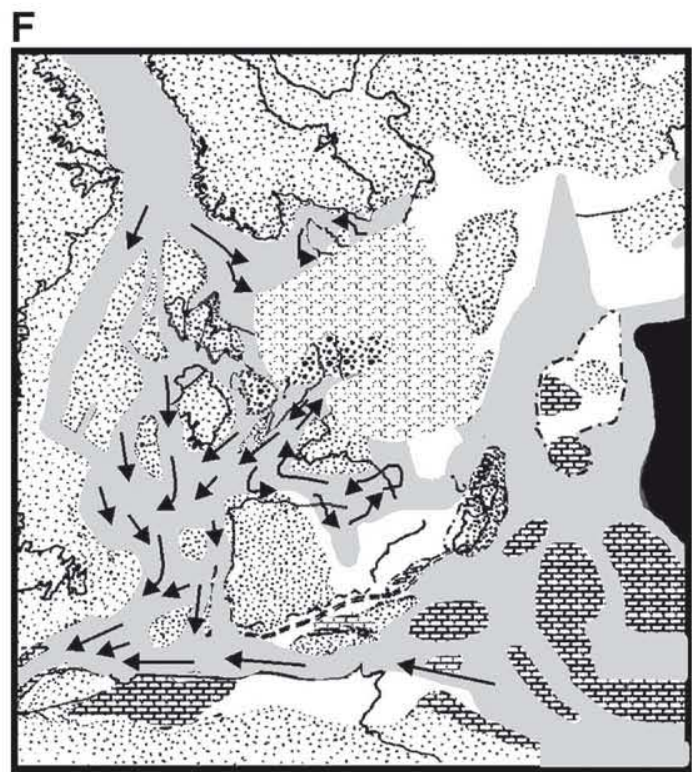

G

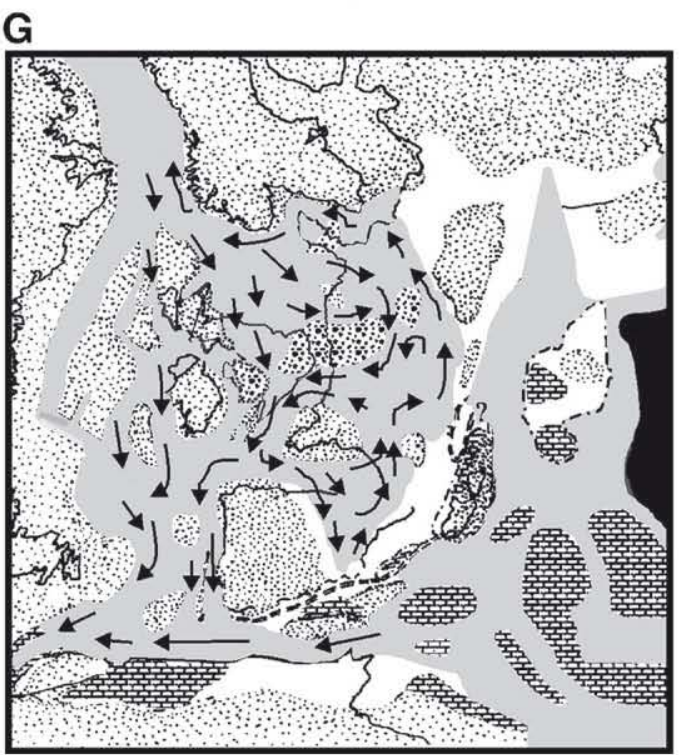

Fig. 3 (continued). persica, K. sermoisensis, Polycope pelta and Praeschuleridea pseudokinkelinella track an anticlockwise gyre migration pattern across of the EES during the bifrons zone (Fig. 3b, G).

\section{Palaeoceanographic control on ostracod distribution}

The majority of marine ostracods are bottomdwelling forms, and only a small number occupy the planktonic realm. A wide range of factors governs the distribution patterns of living ostracod communities. These include physical parameters such as water temperature, salinity and the nature of substrate, ocean currents and biological factors. It is, however, difficult to cite any one control as universally dominant, for while many workers feel that, in the case of marine ostracods in particular, water temperature is the most important, other would argue that salinity is more fundamental, while in costal environments, the nature of substrate may be the overriding influence (Cronin and Dowsett, 1990). 
5.1. Water temperatures: the European Epicontinental Sea water masses

The present-day distribution of ostracod is closely related to water temperature, and therefore former changes in the water temperatures will be reflected in the species composition of fossil ostracod assemblages. Thus, ocean currents and water mass temperatures (due to the ability of ocean currents to modulate the heat transported from the tropics to high latitudes) exert strong controls over the latitudinal distribution of benthic shelf ostracods today, and any variation of the surface and deep-water circulation can alter the position of the boundaries of their zoogeographical provinces. Hence, the analysis of marine ostracod assemblages can provide a unique source of information on ocean palaeotemperatures and, by implication, on changing climatic conditions, enabling researchers to reconstruct changes in the position of water masses in the past (Wood and Whatley, 1994).

Detailed palaeoecological studies have shown that many ostracod species are associated with water masses that possess distinctive thermal characteristic. The properties of the water masses in a shallow sea are constantly changing. Seasonal influences are magnified by the proximity of land, because it varies the annual range in atmospheric temperatures and the freshwater supply through rivers and runoff. This makes the characterization of water masses more difficult to determine than in the deep ocean, where most of the water masses are not in contact with the atmosphere. In the absence of the air-sea contact, the physical properties of water masses can only be transformed when they mix with other water masses of different origins and in consequence, with physical-chemical properties (temperature and salinity). These circumstances complicate the reconstruction of the EES water masses structure.

For the study of the water masses in a shallow sea, such as the Early Jurassic EES, the present author, the model developed by Ziegler et al. (1994, 2003), Scotese (2002) and Winguth et al. (2002) has been adopted. They described the Permian water masses taking into consideration the marine and terrestrial-sensitive sediment distribution and the present-day relationship of sediments to characteristic climate conditions. The EES water masses map was reconstructed by means of the analysis of the marine, nearby terrestrial climate-sensitive sediments and the palaeobiogeographic distribution of ostracod assemblages and other marine fossils (Fig. 4). This method is based on the premise that different sediment types are indicative of very particular marine environments and on the statement, that ostracod species (and other invertebrate fossil groups) have ecological limits controlled mainly by temperature and salinity.

In relation to the first aspect considered, the Early Jurassic world has been commonly interpreted as essentially one in which low-latitude regions were either desert or seasonally summer wet biomes, mid latitude regions were winter wet and warm temperate biomes, while high latitudes were cool temperate biomes (Hallam, 1975; Frakes, 1979; Ziegler et al., 1984; Hallam, 1985; Frakes and Francis, 1988; Zeigler et al., 1998; Gibbs et al., 2002; Zeigler et al., 2003). But this combined faunal, floral and lithological data can be only used to determine Early Jurassic terrestrial climate zones (Vakhrameev, 1964; Hallam, 1984, Vakhrameev, 1991; Hallam, 1994; Rees et al., 2000; Sellwood et al., 2000; Arias and Whatley, 2004). Another type of approximation for describing ocean "biomes" or water masses (as the marine equivalent for the terrestrial biomes) is needed (Ziegler et al., 1998). Using particular salinity and temperature data derive from palaeoclimatic models and palaeodata (Chandler et al., 1992; Frakes et al., 1992; Chandler, 1994; Arias and Whatley, 2004), and the abundance and the distribution of the ostracod assemblage, a three-fold classification of Early Jurassic water masses can be delineated (Fig. 5):

(i) Tropical water masses. Tropical water masses are limited within the $35^{\circ}$ latitude lines and are characterized by having high salinities and temperatures. These conditions allowed abundant bottom productivity and carbonate build-ups in

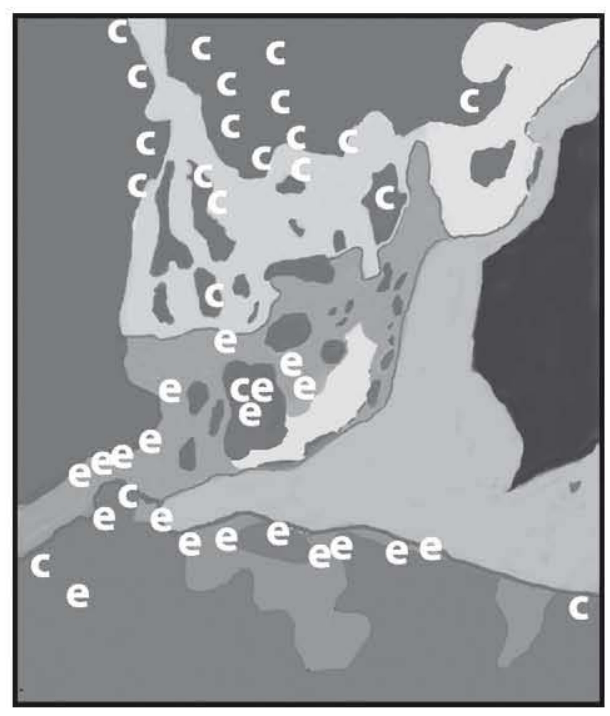

Fig. 4. Early Jurassic evaporite (e) and coal (c) distributions (modified from Frakes, 1979; Parrish et al., 1982; Hallam, 1985; Brandt, 1986; Frakes et al., 1992; Chandler, 1994; Scotese-PALEOMAP Project, 2002). 
areas of good circulation (reef distribution was limited to the northern and western margins of the Tethys Ocean within $5-35^{\circ} \mathrm{N}$ and $\mathrm{S}$ ). In relation to the ostracod fauna, smooth-shelled bairdioids (Bairdia, Pontocyprella, Isobythocypris and Bairdiacypris), ornamented healdioids, in association with a minor number of small cytheroids dominated the assemblages.

(ii) Subtropical water masses. This category is characterized by high salinity and warm water temperature conditions occurring within the central and southern parts of the EES, where important evaporite deposits are frequent (evaporites dominate the south and west sides of the EES, between $40^{\circ} \mathrm{N}$ and $40^{\circ} \mathrm{S}$ of the equator). Most ostracod assemblages described here include a few species of metacopids (Ogmoconcha, Ogmoconchella) and a larger number of large and thicker cytheroids (Ektyphocythere, Kinkelinella, Gramannella, Praeschuleridea and Trachycythere), small cytherurids (Cytheropteron, Infracytheropteron, Rutlandella and Eucytherura) and cytherelloids (Cytherella, Cytherelloidea) as a minor component.

(iii) Temperate water masses. Temperate water masses dominate the northern part of the EES, reaching latitudes as low as $30^{\circ} \mathrm{N}$. This type is defined by brackish conditions similar to the present Baltic Sea. These areas were also characterized by the widespread development of coal deposits around the marginal areas (Ziegler et al., 1994; Rees et al., 2000; Zeigler et al., 2003). Ostracod assemblages from these regions are characterized by having a very low diversity and by comprising mainly smooth healdioids (Ogmoconcha, Ogmoconchella and Pseudohealdia), small cytheroids (Eucytherura, Cytheropteron, Gammacythere and Lophodentina) and bairdioids (Bairdia, Bairdiacypris and Sigilloidea).

The pattern of marine ostracod migration across the EES during the Pliensbachian outlines the distinct water masses. During the Pliensbachian, the migration pattern is characterized by the continuous arrival of Tethyan ostracod faunas into the central and western parts and the Boreal ostracod faunas into the northern parts of the EES. In the EES basins, these movements of ostracod assemblages indicate a complicated temperature-salinity relationship in the EES. The EES deep waters were a complex mixture of waters coming from different areas in the ocean. For example, warm, salty water from the Tethyan Ocean (tropical water masses) entered the EES

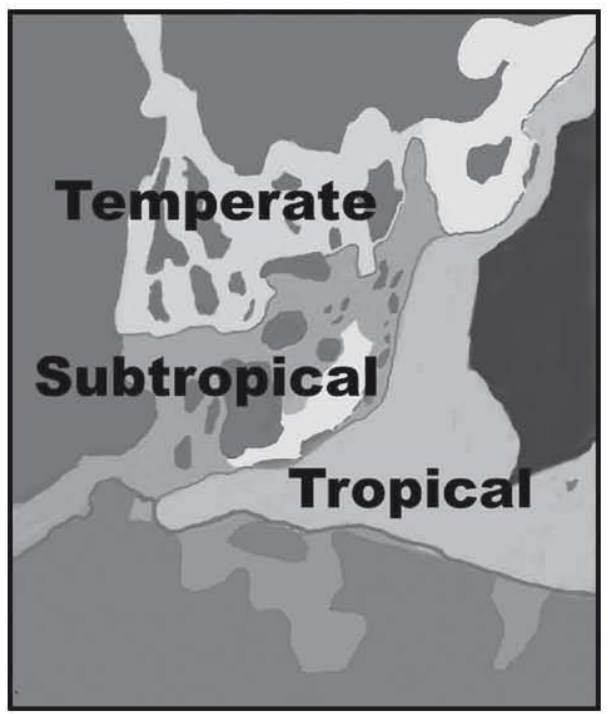

Fig. 5. The ESS water masses in the Early Jurassic. Early Jurassic ocean water masses have been reconstructed based on marine and nearby terrestrial climate-sensitive sediments and the composition and the palaeogeographic distribution of EES ostracod assemblages.

and spread out at intermediate depths (subtropical water masses) displacing intermediate water from Antarctica (temperate water masses) in the north EES, adding additional complexity to the flow as seen in the central part of the Fig. 5 and making possible the survival of some Tethyan forms in the northern parts of the EES. During the Pliensbachian-Toarcian transition, however, the northward drift of warm water Tethyan ostracods was drastically reduced, indicating an alteration of the water temperature. An important water temperature variation, in a marginal sea as the EES was, is generally the result of a significant change in the ocean's circulation or the existence of some kind of physical or environmental barriers between the Tethys Ocean and the EES.

5.2. Communication between the Tethys Ocean and the EES: the EES deep-water circulation and the formation of black shales

Understanding the ostracod migration between the EES and the Tethys Ocean requires a firm comprehension of the EES deep-water circulation. The EES may be considered a marginal semi-enclosed sea as a first approximation, separated from the open Tethys Ocean by shallow sills, semi-barriers or narrow passages (Vöros, 1977; Meister and Stampfly, 2000). The horizontal density differences between the two water masses (the EES and the Tethys Ocean) at the level of the strait, and the inclination of the sea surface in the 
connecting area due to the water exchange, are the two factors that determine the type of communication between the marginal and the open sea.

Using the temperature and salinity values proposed in Early Jurassic climate models (Chandler et al., 1992; Chandler, 1994; Arias and Whatley, 2004), the EES deep waters would comprise three deep-water masses (Fig. 6): (a) the EES Surface water, an upper layer formed in the northern part of the EES, which would flow through the Strait driven by an excess of fresh water input over loss by evaporation; (b) the EES Intermediate water, which would be composed of one or maybe two water masses formed in the northern side of the basin; and (c) the Tethyan Deep water, characterized by its constancy over the western part of the EES basin, high temperature and high salinity and that penetrated deep into the EES.

Two aspects must be firstly considered before analyzing the communication between water bodies, the existence of sills or some sort of barrier and the sealevel changes. The Early Jurassic was a period of tectonic plate reorganization, with the break-up of the Pangaea, which involved rifting and the opening and closing of oceanic seaways, as well as changes in longterm eustatic sea-levels (Hallam, 1978; Liu et al., 1998). Physical barriers, such as shallow carbonate platforms or emerged land belts along the southern part of the EES (for example, the Briaconnais and Corso-Sardinia blocks or the Balearic and pre-Betic platforms) might have acted as a barrier separating the EES from the Tethys Ocean (Alméras and Elmi, 1987). Only a few areas may have temporally worked as entry passageways (for example, the Lower Austroalpine, South Calcareous Alps, the Balcony Mounts, the Burgundy area or the Sub-Briaconnais area) along the southern margin of the EES (Dommergues and Meister, 1991; Meister and Stampfly, 2000). The opening of these passageways would be responsible for the north-south direction of the boundary during Pliensbachian.

The passageways between the sea and the open ocean were often narrow and shallow and so were extremely sensitive to rises and falls in eustatic sea level. Low stands reduce open seaways and the spread of the ostracod faunas; whereas, high sea levels facilitate faunal exchange, leading to an increase in overall diversity and extensive distribution of the ostracod assemblages. The Early Jurassic was a time of major sea-level transgressions and regressions (Fig. 7) on both regional and global scales, with an overall trend towards lower sea-level from the Late Triassic (Hesselbo et al., 2004) to the Hettangian, across the Pliensbachian-Toarcian boundary and in the latest Toarcian (Hallam, 1984); and towards high sea levels during the latest Hettangian, latest Sinemurian, mid Pliensbachian, mid Toarcian and

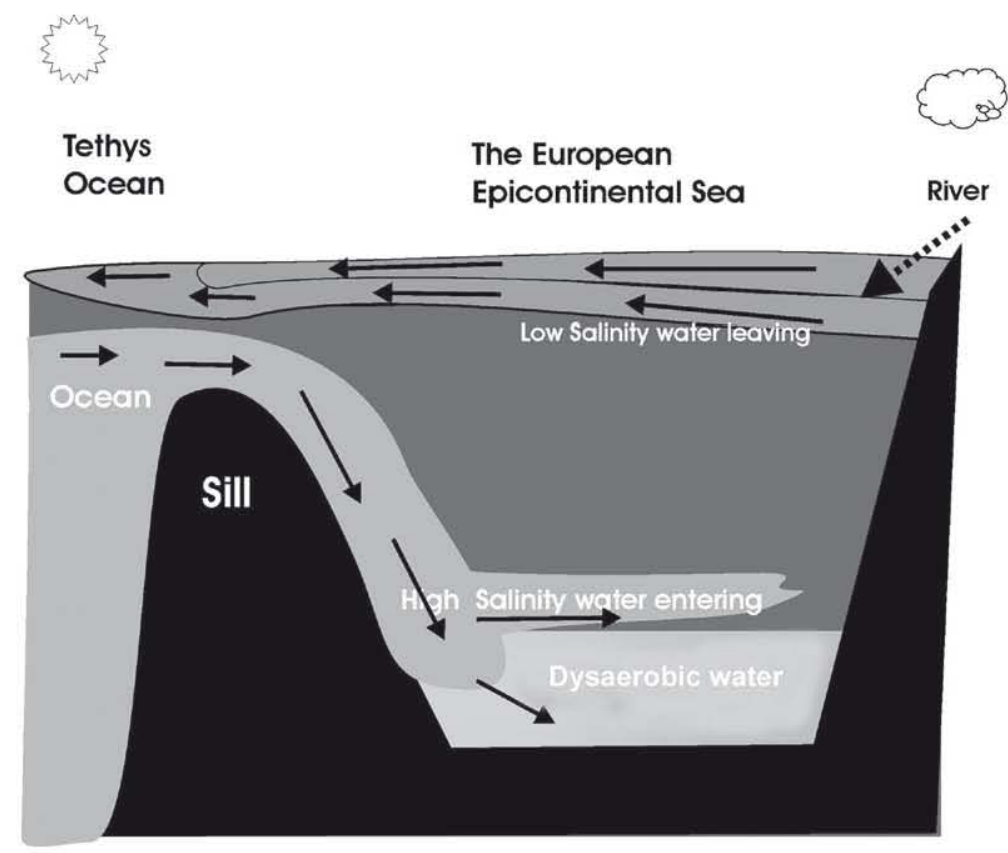

Fig. 6. Interchange of water masses between the EES and the Tethys Ocean. The water flowing into the EES came out of Laurasian rivers and had a low density. This relatively low salty water mixed with the seawater and flowed into the Tethys Ocean. The deeper waters were saltier, denser and thus could not flow over the shallow sill into the Tethys Ocean. 
Late Toarcian (Vail et al., 1977; Hallam, 1978, 1984; Haq et al., 1987, 1988; Cope, 1988; Hardenbol et al., 1998; Gómez and Goy, 2002).

As it was discussed in the former section, the most important change in the ostracod migration pattern took place during the falciferum zone, Early Toarcian (Fig. 3b, F), when the connection among British, French and German basins was blocked, with only the communication between French and Spanish basins remaining active. The existence of these physical barriers that ostracods cannot pass through may explain the end of the communication between central EES basins.

Nevertheless, there are indications that the ending of the entrance of the Tethyan faunas and the disruption in the migration pattern of ostracod faunas in the central EES may be due less to palaeogeographic factors than to environmental factors (e.g. changes in the water temperature or salinity values or a low oxygen contents. The development of marine anoxia and the black shales are generally regarded as the proximate cause of the Toarcian losses, with the release of gas hydrates further contributing to the high-stress environmental changes. However, two crucial aspects, the relative timing and the origin of these phenomena, are not completely comprehended. The monsoonal activity may have been the driving factor for the formation of black shales deposition. The freshening of the surface waters resulting from excess rain and freshwater input from rivers during monsoonal summer conditions over the northern margin of the sea is envisaged to increase the stratification and reduced the density of the surface layer. These circumstances would have prevented the freshened water from reaching the deeper layers. The result would have been the establishment of a fresh upper layer that may have formed a cap, which could have prevented oxygen transfer to the denser saline water. Water below the halocline would have been renewed only very slowly through mixing across the halocline and by the inflow of oceanic water through the connecting strait. Oxygen at depth could have been consumed by similar process (such as the remineralization of nutrients) to those described in the present Black Sea.

But there is another factor to consider: the depth of the sill. If the sill was not lying low enough below the level of the less dense top layer, the heavier water of the open ocean could not have flowed unimpeded across the sill, thus the circulation renewal of the deep water could not have been initiated. The anoxia could have taken place when the strait between the EES and the Tethys was very shallow as a consequence of some kind of regressive trend or tectonic reactivation of major pre-existing structures related to the opening of the Hispanic Corridor.

Additional information about palaeoceanographic conditions can be obtained from the isotopic record. Lower Toarcian sequences of carbon-rich black shales

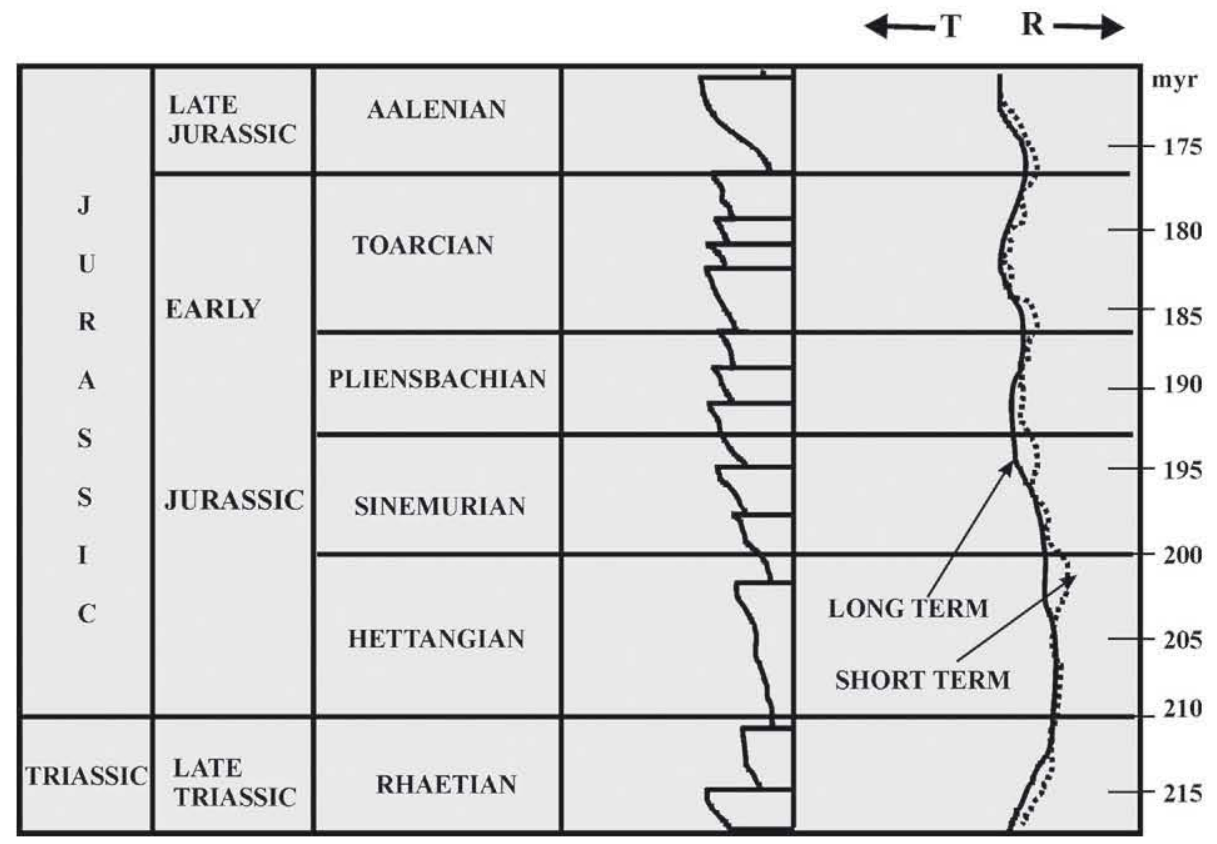

Fig. 7. Sea-level cycles (adapted from Vail et al., 1977; Haq et al., 1987, 1988). 
along the EES show a $\delta^{13} \mathrm{C}$ minimum in the uppermost tenuicostatum and the falciferum zones of the Toarcian (Jenkyns and Clayton, 1986, 1997; Hesselbo et al., 2000; McArthur et al, 2000; Jenkyns et al., 2002; Rosales et al., 2004). Two explanations have been given for the cause of this negative $\delta^{13} \mathrm{C}$ excursion: Firstly, by the recycling of remineralized carbon from the deeper parts of an intermittently stratified water column up into the photic zone, where it would have been incorporated by photosynthetic phytoplankton (Sælen et al., 2000; Schouten et al., 2000; Röhl et al., 2001; Schmid-Röhl et al., 2002). Secondly, a number of authors have suggested that the negative $\delta^{13} \mathrm{C}$ isotope exclusion resulted from the rapid release of carbon dioxide to the ocean-atmosphere system from dissociation of methane hydrate (Hesselbo et al., 2000; Jenkyns, 2003). Because biogenic methane is depleted in $\delta^{13} \mathrm{C}$ relative to $\delta^{12} \mathrm{C}$ its subsequent oxidation to carbon dioxide in the oceans and atmosphere leaves a light carbon isotope signal on ocean dissolved inorganic (DIC) carbon and, shifting their isotopic composition towards more negative values (Küspert, 1982; Jenkyns, 1988; Röhl et al., 2001; Van de Schootbrugge et al., 2005).

According to the EES deep-water structure (Fig. 6), the development of this negative anomaly are related to the formerly described palaeoceanographic conditions (i.e. the combination of a restrictive circulation together with a significant density stratification in the EES) during the tenuicostatum-falciferum transition, which may explain the low ostracod abundance and diversity described at the beginning of the falciferum zone (Fig. 8). Nevertheless, the Toarcian Anoxic Event cannot explain why the incursions of the Tethyan ostracod faunas into the western part of the EES ceased, or why the direction of the ostracod migration changed at the beginning of the Toarcian (Fig. 3a). Another explanation can be related to a rapid change of water temperature along the EES.

\subsection{Surface oceanic general circulations in the EES: a possible collapse of the deep-water circulation}

Bottom temperatures of deep ocean water masses do not show the north-south latitudinal gradient because deep-water masses are formed through density-driven processes (salinity and temperature). Subsequently, the deep-water temperatures reproduce those at the origin of the water mass formation, with negligible mixing occurring at water masses boundaries. Therefore, once formed, deep-water masses hold characteristic temperature and salinity signatures that could be traced in the
EES. The occurrence of warm marine ostracod faunas in the EES during the Pliensbachian could be used to draw the spreading out of the Tethyan Deep Water. Hence, changes in the properties of such deep waters across the EES basin can be only the result of significant salinity of temperature global changes, which could modify the properties of the water masses. Observational and modelling evidences and the analysis of the sedimentary and fossil records suggest that the poleward ocean heat transport haves varied as a response to palaeogeographic and palaeoceanographic changes (Chandler et al., 1992; Arias and Whatley, 2004).

The migration of warm Tethyan ostracods into the EES during the Pliensbachian-Toarcian Boundary (the PTB) is indicator that water temperatures were high enough to permit their survival in the Boreal EES. The end of the northward migration of the Tethyan faunas could be explained in part by a major sudden cold event. A reduction in ocean heat transport to the high-latitude EES, associated with the reduction, shutdown, or southward shift in the formation of the EES deep water may be hypothesized to have caused or amplified the abrupt cooling event.

Early Jurassic climate simulations show a Pangaea supercontinent characterized by the development of monsoonal circulation, with low-pressure cells sited over the eastern margin of the EES during the summer (Fig. 9A) and over the central parts of the Gondwana in the winter (Fig. 9B). High pressure cells are situated over the southern Gondwana (far away from the EES) during the summer (Fig. 9A), forming a large belt crossing the EES during the winter (Fig. 9B), with one high pressure cell over Siberia and another over the northwestern Gondwana (Parrish and Curtis, 1982; Parrish et al., 1982; Kutzbach, 1985; Robertson and Ogg, 1986; Scotese and Summerhayes, 1986; Crowley et al., 1987; Crowley, 1988; Kutzbach and Gallimore, 1989; Chandler et al., 1992; Fawcett et al., 1994). The monsoonal character of the atmospheric circulation over the EES generated the development of weak westerlies over most of the northern part of the EES and strong easterlies over the central parts of the EES during the winter. But in the summer, westerly winds are replaced by weak easterlies in the northern part of the EES.

These winds create Ekman convergence in the mid latitude EES, driving the subtropical gyre. The northern side of the westerlies creates Ekman divergence at the higher latitudes of the EES, driving the subpolar circulation. Consequently, the flow of the trades and westerlies induces the formation of a clockwise circulation in the EES. The Fig. 10 shows a broad, basin-wide, mid latitude gyre as we expect from Sverdrup's theory. In the west, a western boundary 


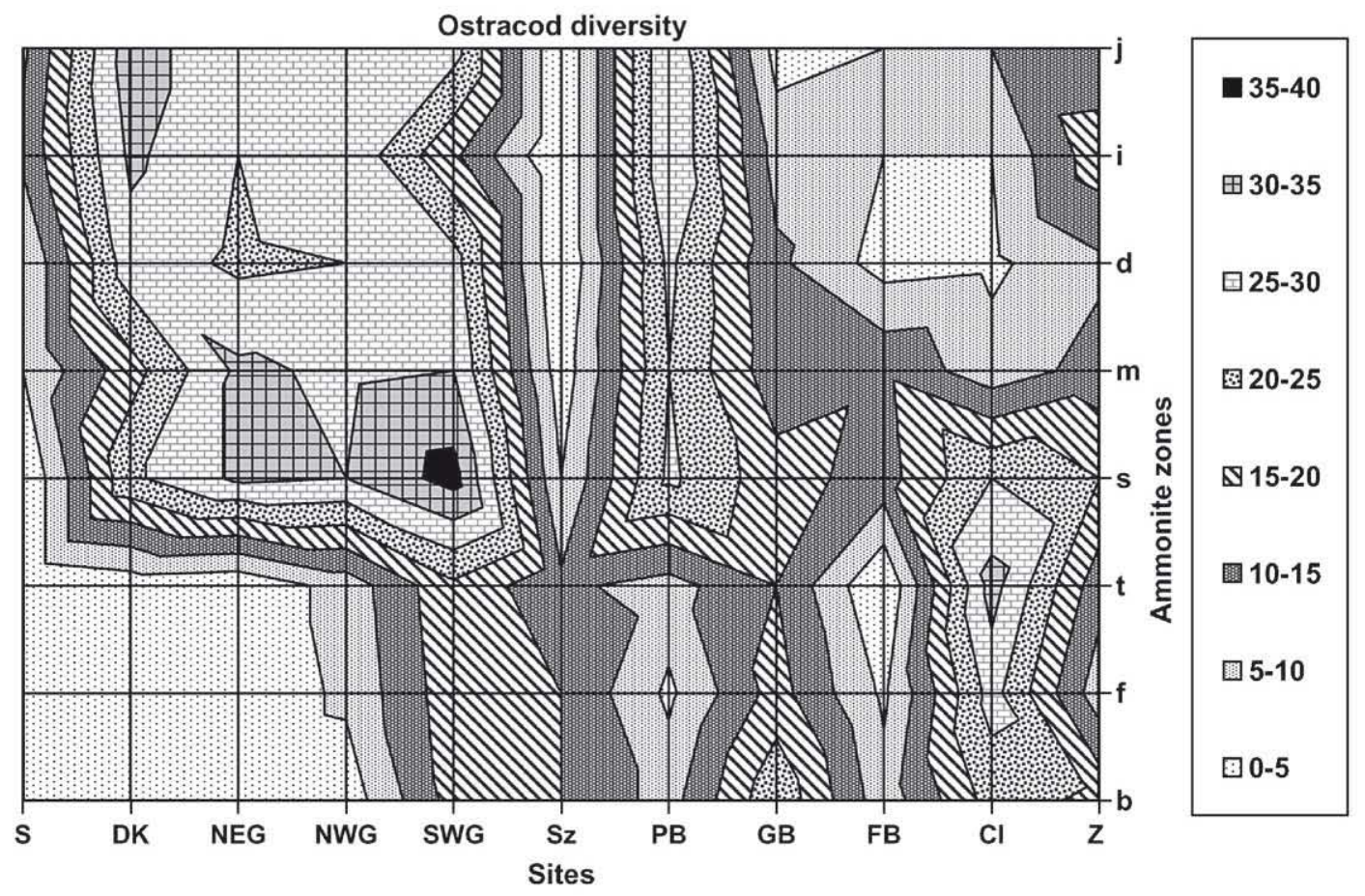

Fig. 8. Plot of the ostracod species diversity in the Pliensbachian to Toarcian successions of the European Epicontinental Sea. Sites: Z: Zambujal, Portugal; CI: the Cordillera Ibérica, North East Spain; FB: the Fastnet Basin, South West Ireland; GB: Central and Southern England and Wales; PB: the Paris Basin, France; Sz: NE Swiss basins; SWG: Southwestern German basins; NWG: Northwestern German basins; NEG: Northeastern German basins; DK: Danish basins; and S: Swedish basins. Ammonite zones: (j) jamesoni zone; (i) ibex zone; and (d) davoei zone of the Early Pliensbachian; (m) margaritatus zone and (s) spinatum zone of the Late Pliensbachian; and (t) tenuicostatum zone; (f) falciferum zone; and (b) bifrons zone of the Early Toarcian.

current, a pre-Gulf Stream, completes the gyre. Therefore, this subtropical gyre's western boundary current is a pre-Gulf Stream system, which is off the east coast of Northern Pangaea, along the western margin of the EES. Much of the heat-transported poleward by the oceans is carried by these sorts of mid latitude western boundary currents in the Northern Hemisphere. As these currents separate from the coastal boundaries, extend eastward into the EES interior, they flux some of their heat to the atmosphere and store some of their heat in the subtropical gyre. A weakening of this system would cause a cooling episode in the EES.

In the present paper it is proposed that the opening of the Hispanic Corridor could have disrupted the system. The opening of the Hispanic Corridor (a new route through the Caribbean region) by the Late Pliensbachian (Kocurek and Dott, 1983; Robertson and Ogg, 1986; Damborenea, 2000; Aberhan, 2001; Arias, 2006) may have modified this palaeoceanographic system by means of the development of a new westward equatorial current from the Tethys to the Panthalassa Oceans, which would have weakened this "pre-Gulf Stream" and consequently, would have affected the surface and deep- water circulation. The shut-off of this pre-Gulf Stream not only greatly reduced the transport of warm water in the EES, producing a moderate cold northern hemisphere climate, but it may have reinforced the cold water transport from the Arctic Ocean to the EES, leading to the beginning of a temperature decline episode. In summary, if the deep-ocean thermohaline circulation was shut off, the influx of warm, salty water from the Tethys would decrease and the water temperature in the EES might become cooler, making impossible the survival of warm ostracod faunas.

\section{Conclusions}

The analysis of the Pliensbachian-Toarcian ostracod palaeobiogeography has allowed obtaining information about the surface and deep-water circulations and has made it possible to propose a new palaeoceanographic reconstruction of the Early Jurassic European Epicontinental Sea (EES). The additional information from other fossil groups also enhanced the reconstruction of the evolution of the local circulation in the EES. 
The Pliensbachian was a period of maximum expansion for ostracod faunas throughout the EES, characterized by a southward migration of the faunas and by the development of an anticlockwise migration inside the Central European basins. The Early Jurassic ostracod migration pattern is initially explained in the broader context of the EES deep oceanic circulation and in its variations, as a consequence of the palaeogeographic and palaeoenvironmental changes.

Considering the ostracod migration pattern, the combined faunal and lithological data and the EES and Tethyan salinity and temperature distribution derived from climate models, an integrated three-fold classifica-
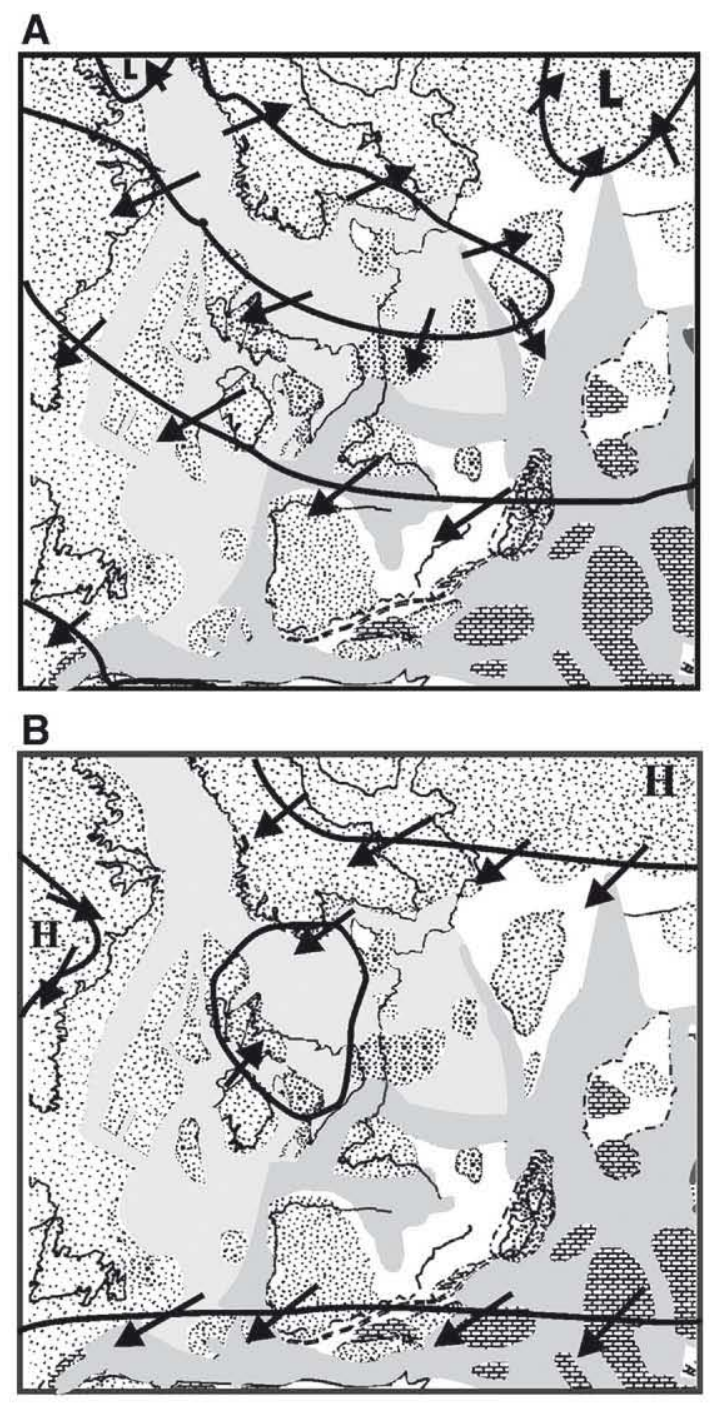

Fig. 9. (A) Atmospheric and oceanic circulation (PliensbachianToarcian) during summer in the Northern Hemisphere; (B) during winter in the Northern Hemisphere (adapted from Parrish et al., 1982; Scotese and Summerhayes, 1986; Chandler et al., 1992).

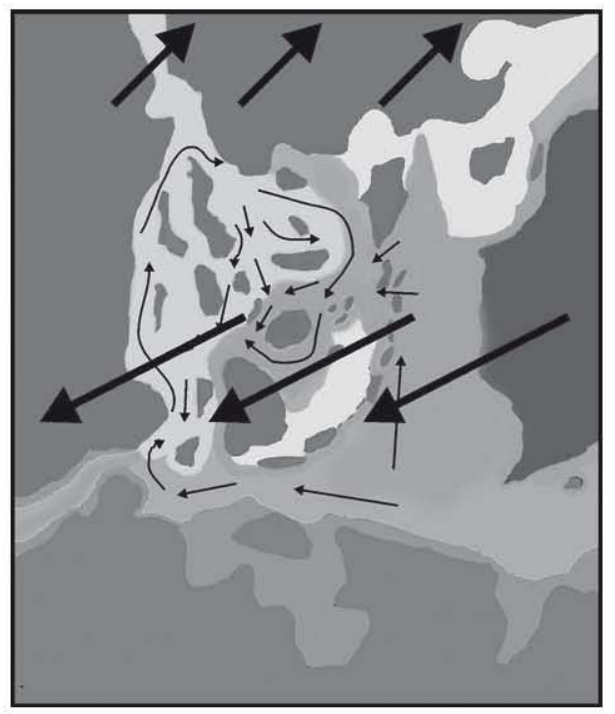

Fig. 10. Surface currents patterns in the European Epicontinental Sea. The prevailing easterlies in conjunction with the westerlies create surface current flow within the subtropical gyre. Narrow black arrows show the direction of surface currents.

tion of water masses (tropical, subtropical and temperate) has been proposed. In this model the deep-water circulation would be of an estuarine type, with warm water from the Tethys flowing northwards at depth to the EES and superficial cold and freshening water flowing out from the EES to the Tethys Ocean. Deep waters are presumed to have been formed in the small basins along the southern margin of the EES due to the high evaporation expected at this latitude (indicated by the presence of evaporite deposits). As a result, the deep water filling the ESS was warmer. This assumption is consistent with estimated palaeotemperatures and with the low temperature gradients between the northern latitudes and the tropics during the Pliensbachian.

This migration pattern changed, however, by the latest tenuicostatum-early serpentinus transition, when the interruption of the entrance of Tethyan forms into the central EES and the end of the communication between the western and central basins of the EES took place. A possible change of the former described EES deep-water circulation is considered for explaining this change. The alteration of the EES deep-water structure due to palaeogeographic (the opening of the Hispanic Corridor) and sea-level variations modified the inflow of Tethyan waters and therefore the stratification of water masses in the EES. This modification of the density stratification and the resultant anoxia has been suggested as a possible mechanism of black shales formation and Toarcian ostracod extinction. 
However, the main disruption of the EES deep-water circulation, in the present paper, is linked to the change of the surface ocean circulation resulting from the opening of the Hispanic Corridor. The clockwise surface circulation derived from Early Jurassic atmospheric circulation models across the EES changed as a consequence of the opening of the Hispanic Corridor during the Toarcian because this event altered the gyral circulation with the development of a new westward equatorial surface current from the Tethys to the Panthalassa Oceans and the weakened of the pre-Gulf Stream current along the EES. As a result, the deepwater circulation was disrupted, modifying the inflow of warm Tethyan waters into the EES and lending to a radical climate change in many areas around the EES. The low temperatures resulting from this event impeded the entrance of warm ostracod species from the Tethys into the EES at the beginning of Toarcian.

\section{Acknowledgments}

An early version of the manuscript benefited from the careful reviews of Professor Robin Whatley (University of Wales, Aberystwyth) and Professor Pat Wilde (University of California, Berkeley), who are both warmly thanked. We thank Dr. Bas van de Schootbrugge (Universität Frankfurt am Main) and Professor Antonio Goy (UCM, Madrid) for their stimulating discussions and enthusiastic support. I would like to thank Dr. Ian Boomer of the University of Newcastle for their helpful discussions and constructive comments and for taking the time to comment on the several chapters, which improved the manuscript, and also Dr. Nigel Ainsworth who kindly suggested improvements that did much to augment the readability of the final manuscript. My debt to Dra. Alicia Moguilevsky and the Translations Group's translators and Emma Benzal for their helpful improvements and English corrections. I would like to express my thanks to the long-term financial support from the support by the Projects CGL 2005-01765/ BTE and CGL-2005-04574/BTE from the Ministerio de Educación y Ciencia (Spain) and the Project UCM-CAM-No. 910431 from the Comunidad de Madrid (Spain).

\section{References}

Aberhan, M., 2001. Bivalve palaeobiography and the Hispanic Corridor: time of opening and effectiveness of a Proto-Atlantic seaway. Palaeogeography, Palaeoclimatology, Palaeoecology, Amsterdam 165, 375-394.

Ager, D.V., 1956. The geographical distribution of brachiopods in the British Middle Lias. Quarterly Journal of the Geological Society of London, London 112, 157-187.
Ager, D.V., 1960. Brachiopod distributions in the European Mesozoic. Report International Geological Congress, XXI Session, Norgen $22,20-25$.

Ager, D.V., 1971. Space and time in brachiopod history. In: Middlemiss, F.A., Rawson, F.A., Newal, G. (Eds.), Faunal provinces in space and time. Geological Joumal, vol. 4, pp. 95-110.

Ager, D.V., 1973. Mesozoic Brachiopods. In: Hallam, A. (Ed.), Atlas of Palaeobiogeography. Elsevier, Amsterdam, pp. 431-436.

Ager, D.V., Walley, C.D., 1977. Mesozoic Brachiopod Migrations and the Opening of the North Atlantic. Palaeogeography, Palaeoclimatology, Palaeoecology, Amsterdam 21 (2), 85-99.

Ainsworth, N.R., 1986a. Rhaetian, Hettangian and Sinemurian Ostracoda from the Fastnet Basin, offshore Southwest Ireland. Bulletin of the Geological Survey of Ireland 4, 107-150.

Ainsworth, N.R., 1986b. Toarcian and Aalenian Ostracoda from the Fastnet Basin, offshore Southwest Ireland. Bulletin of the Geological Survey of Ireland 3, 277-336.

Ainsworth, N.R., 1987. Pliensbachian Ostracoda from the Fastnet Basin, offshore Southwest Ireland. Bulletin of the Geological Survey of Ireland 4 (1), 41-62.

Ainsworth, N.R., 1989. Remarks on the nomenclature of two ostracod species from the Pliensbachian and upper Toarcian-Aalenian of the Fastnet Basin, offshore Southwest Ireland. Bulletin of the Geological Survey of Ireland 4 (2), 165-166.

Ainsworth, N.R., Horton, N.F., 1987. Mesozoic micropaleontology of exploration well Elf 55/30-1 from the Fastnet Basin, offshore southwest Ireland. Journal of Micropaleontology 5 (1), 19-29.

Ainsworth, N.R., 'Neill, O., Rutherford, M., Clayton, M.M., Horton, G., Penney, N.F., 1987. Biostratigraphy of the Lower Cretaceous, Jurassic and uppermost Triassic of the North Celtic Sea and Fastnet Basin. In: Brooks, J., Glennie, K., Trotman, M. (Eds.), Petroleum Geology of North West Europe. Graham and Trotman Ltd, London, pp. 611-622.

Alméras, Y., Elmi, S., 1987. Evolution des peuplements des brachiopodes en fonction de l' environnent dans le Lias ardéchois. Cahiers Scientifiques de l'Université Catholique de Lyon, Science, Lyon 1, 21-56.

Alméras, Y., Elmi, S., 1993. Palaeogeography, physiography, paleoenvironments and brachiopod communities. Examples of the Liassic brachiopods in the Western Tethys. Palaeogeography, Palaeoclimatology, Palaeoecology, Amsterdam 100 (1-2), 95-108.

Alméras, Y., Faure, P., 2000. Les brachiopodes liassiques del pyrénéens, paleontologie, biostratigraphie, paleobiogeographie et paleoenvironnants. Strata 2 (36), 1-395.

Alméras, Y., Moulan, G., 1982. Les Terebratulides liasiques de Provence. Paleontologie, biostratigraphie, paléoécologie, phylogénie. Documents des Laboratoires de Géologie de la Faculté des Sciences de Lyon 86, 1-365.

Andreu, B., Bodergat, A.M., Brunel, F., Colin, J.P., Cubaynes, R., 1998. Ostracodes du Carixien supérieur-Domérien (Jurassique inférieur) du Quercy, Bassin d'Aquitaine, France. Palaeontographica A 250, 68-122.

Apostolescu, V., 1959. Ostracodes du Lias du bassin de Paris. Revue de l' Institut français de Pétrole Paris 15 (6), 795-817.

Apostolescu, V., 1961. Sud du Bassin, Région D'Argenton-sur-Creuse et de la Châtre (Départements du Cher et de l'Indre). Ostracodes. In: Cousin, N., Espatilier, J., Sigal, J., Apostolescu, V. (Eds.), Colloque sur le Lias français. Mémoire Bureau Recherche Géologiques Minières, vol. 4, pp. 445-449.

Apostolescu, V., Magne, J., Malmoustier, G., 1961. Quelques espèces nouvelles d 'Ostracodes du Toarcien de Thouars (Deux-Sèvres). 
In: Cousin, N., Espatilier, J., Sigal, J., Apostolescu, V. (Eds.), Colloque sur le Lias français Mémoire Bureau Recherche Géologiques Minières, vol. 4, pp. 399-415.

Arias, C., 1993. Upper Domerian and Lower Toarcian Ostracoda from the Umbria-Marche Basin, Central Italy. Bollettino della Societá Paleontologica Italiana 32, 367-383.

Arias, C., 1995. Los ostrácodos del Toarciense inferior en la Cordillera Tbérica. Unpub. PhD thesis. Fac. CC Geologicas, Universidad Complutense de Madrid, pp. 521.

Arias, C., 1997. Ostracod bioestratigraphy of the Lower Toarcian in the Cordillera Iberica, northern Spain. Neue Jahrbuch für Geologie und Paläontologie Abhandlungen 206 (1), 67-91.

Arias, C., 2000. The Pliensbachian-Toarcian boundary Ostracod Bioestratigraphy in the Cordillera Iberica, northeastern Spain. Neue Jahrbuch für Geologie und Paläontologie Abhandlungen 216 (2), 153-19.

Arias, C., 2006. Northern and Southern Hemisphere Northern and Southern Hemispheres ostracod palaeobiogeography during the Early Jurassic: possible migration routes. Palaeogeography, Palaeoclimatology, Palaeoecology 233 (1-2), 63-95.

Arias, C., Lord, A., 1999a. Upper Pliensbachian and Lower Toarcian Ostracoda from the Cordillera Ibérica, North-East Spain. Part 1. Revista Española de Micropaleontología 31 (1), 73-98.

Arias, C., Lord, A., 1999b. Upper Pliensbachian and Lower Toarcian Ostracoda from the Cordillera Iberica, North-east Spain. Part 2. Revista Española de Micropaleontología 31 (2), 219-242.

Arias, C., Whatley, R., 2004. Distribution patterns of Early Jurassic ostracod and possible communication routes across the European Epicontinental Sea: evidence changes in ocean circulation patterns and its consequence to climate change. Neue Jahrbuch für Geologie und Paläontologie Abhandlungen 232 (1), 1-55.

Babinot, J.F., Colin, J.P., 1992. Marine ostracod provincialism in the Late Cretaceous of the Tethyan realm and the Austral Province. Palaeogeography, Palaeoclimatology, Palaeoecology, Amsterdam 92, 283-293.

Barbieri, F., 1964. Micropaleontologia del Lias e Dogger del Pozzo Ragusa I (Sicilia) (I). Rivista Italiana de Paleontologia e Stratigrafia, Milano, LXX 4, 709-830.

Bartolini, A., Larson, R.L., 2001. Pacific microplate and the Pangea supercontinent in the Early to Middle Jurassic. Geology 29, 735-738.

Bassoullet, J.P., Poisson, A., Elmi, S., Cecca, F., Bellion, Y., Gurirand, F., Baudin, F., 1992. Mid Toarcian (184-182 m.a.). Téthys Paleomaps. In: Bassoullet, J.P., Elmi, S., Cecca, F., Le Nindre, J.Y., Manivit, J., Poisson, A. (Eds.), Paléogéographie du domaine téthysien au Toarcien. Réunion Téthys, Paris, pp. 1-19.

Bate, R.H., Coleman, B.E., 1975. Upper Lias Ostracoda from Rutland and Huntingdonshire. Bulletin of the Geological Survey of Great Britain, London 55, 1-42.

Bizon, J.J., 1960. Sur quelques ostracodes du Lias du Bassin parisien. Revue de Micropaléontologie 2, 203-211.

Bizon, J.J., Oertli, H., 1961. Lorraine, région de Nancy et Thionville. In: Cousin, N., Espatilier, J., Sigal, J., Apostolescu, V. (Eds.), Colloque sur le Lias français. Mémoire Bureau Recherche Géologiques Minières, vol. 4, pp. 433-436.

Blake, J.F., 1876. Class Crustacea. In: Tate, R., Blake, J.F. (Eds.), The Yorkshire Lias (Eds.), London, pp. 429-435.

Bodergat, A.M., Donze, P., 1988. Biostratigraphical scale in Toarcian of the Paris Basin. In: Hanai, T., Ikeya, N., Ishizaki, K. (Eds.), Biology of Ostracoda. . Fundamental and Applications. Proceeding of the Ninth International Symposium on Ostracoda, Shizouoka, Japan, vol. 11. Developments in Paleontology and Stratigraphy, Elsevier, pp. 1261-1267.
Bodergat, A.M., Donze, P., Nicollin, J.P., Ruget, C.H., 1985. Répartition biostratigraphique des microfaunes toarciennes en bordure du Bassin de Paris. Les Cahiers de l' Institut Catholique de Lyon, Lyon 14, 103-121.

Bodergat, A.M., Cubaynes, R., Courtinal, B., Ruget, C.H., 1991. Stratégies adaptatives $\mathrm{K}$, $\mathrm{r}$ et dans $\mathrm{l}^{\mathrm{e}}$ évolution des Ostracodes du Toarcien quercynois (France). Comptes Rendus de l'Académie des Sciences 312 (2), 1177-1182.

Bodergat, A.M., Bonnet, L., Colin, J.P., Cubaynes, R., Rey, J., 1998. Opportunistic development of Ogmoconcha amalthei, ostracod, in the lower liassic of Quercy (SW France) an indicator of sedimentary disturbance. Palaeogeography, Palaeoclimatolology, Palaeoecolology, Amsterdam 143, 179-190.

Boomer, I., 1988. On Ektyphocythere anterocosta sp. nov. Boomer. Stereo-Atlas of Ostracod Shells, Leicester, 15, 21, 93-96.

Boomer, I., 1991. Lower Jurassic ostracod biozonation of the Mochras Borehole. Journal of Micropaleontology 9 (2), 205-218.

Boomer, I., 1992. Lower Jurassic ostracods from Ilminster, Somerset, England. Journal of Micropaleontology 11 (1), 47-57.

Boomer, I.D., Lord, A.R., 1988. On Ektyphocythere quadrata sp. nov. Boomer and Lord. A Stereo-Atlas of Ostracod Shells 15 (19), 85-88.

Boomer, I., Bodergat, A.M., 1992. On Cytheropteron byfieldensis $\mathrm{sp}$. nov. Boomer and Bodergat. Stereo-Atlas of Ostracod Shells, Leicester 19 (1), 1-4.

Boomer, I., Ainsworth, N., Exton, J., 1998. An re-examination the Pliensbachian and Toarcian ostracode of Zambujal, west-central Portugal. Journal of Micropaleontology 17, 1-14.

Boutakiout, M., Donze, P., Oulmach, F., 1982. Nouvelles espèces d'ostracodes du Lias moyen et supérieur du Jbel Dhar en Nsour (rides sud-rifaines, Maroc Septentrional). Revue de Micropaléontologie, Paris 25 (2), 94-104.

Braga, J.C., Jiménez Jiménez, A.P., Rivas, P., 1982. Los Hildoceratidae del tránsito Domèriense-Toarciense de la Zona Subbetica (Cordillera Betica, sur de España). Boletin de la Real Sociedad de Historia Natural 80, 133-152.

Brandt, K., 1986. Glacioeustatic cycles in the Earth Jurassic? Neue Jahrbuch für Geologie und Paläontologie Monatsheft, Stuttgart, 5, 257-274.

Cariou, E., Hantzpergue, P., 1997. Biostratigraphie du Jurassique Ouest-Européen et Méditerranéen: Zonations Parallèles et Distribution des Invertébrés et Microfossiles, Bulletin de la Centre Recherches d'Elf Exploration Production, Mémoires 17, Elf Exploration Production, Pau Cedex, pp. 1-422.

Cariou, E., Contini, D., Dommergues, J.L., Enay, R., Geyssant, J.R., Mangold, C., Thierry, J., 1985, Biogéographie des Ammonites et évolution structurale de la Téthys au cours du Jurassique: Bulletin de la Société Géologique de France 5, 679-697.

Champeau, H., 1961. Étude de la microfaune du niveau marneux du Lias dans le sud-est du Bassin de Paris. In: Cousin, N., Espatilier, J., Sigal, J., Apostolescu, V. (Eds.), Colloque sur le Lias français. Mémoire Bureau Recherche Géologiques Minières, 4, pp. 437-443.

Chandler, M.A., 1994. Depiction of modern and Pangaean desert: Evaluation of GCM hydrological diagnostics for paleoclimates studies. In: Klein, G.D. (Ed.), Pangaea: paleoclimate, tectonics and sedimentation during Accretion, Zenith and Break-up of a supercontinent. Geological Society of America Special Paper, vol. 288. Boulder, Colorado, pp. 117-137.

Chandler, M.A., Rind, D., Ruedy, R., 1992. Pangaean climate during the Early Jurassic: GGCM simulations and the sedimentary record of paleoclimate. Geological Society of America Bulletin, New York 543-559. 
Choffat, P., 1947. Description de la faune Jurassique du Portugal. Brachiopodes. Service Géologique Português, Lisbon 1-46.

Cope, J.C.W., 1988. Discussion on estimates of the amount and rate of sea-level change across the Rhaetian-Hettangian and Pliensbachian-Toarcian boundaries (latest Triassic to Early Jurassic). Journal of Geology Society of London, London 155, 1-421.

Coryell, H., 1963. Bibliographic index and clasification of the mesozoic ostracoda 2 Bde. University Dayton Press, Dayton, Ohio, pp. 1-1175.

Cousin, N., Apostolescu, V., 1961. Ostracodes. In: Cousin, N., Espatilier, J., Sigal, J., Apostolescu, V. (Eds.). Colloque sur le Lias français. Ardennes, région de Mézières (Département des Ardennes. Mémoire Bureau Recherche Géologiques Minières 4, 423-431.

Cronin, T.T., Dowsett, H.J., 1990. A quantitative micropaleontologic method for shallow marine Paleoclimatology: application to Pliocene deposits the western North Atlantic. Marine Micropaleontology 16, 117-147.

Crowley, T.J., 1988. Paleoclimate modelling. In: Schlesinger, M.E. (Ed.), Physically based modelling and simulation of climate and climatic change, part II. Kluwer Academic, Boston, pp. 883-949.

Crowley, T.J., Mengel, J.G., Short, D.A., 1987. Gondwanaland's seasonal cycle. Nature London 329, 803-807.

Cubaynes, R., 1986. Le Lias du Quercy Méridional, études lithologique, biostratigraphique, paléoécologique et sédimentologique. Thèse de l'Université Pau Sabatier, Toulouse-3 1268, Strata 2 (6) pp. 1-574.

Cubaynes, R., Ruget, C., 1985. Les Ecosequences de Nodosariides et d'ostracodes et leur significations dans les Marines Toarciennes du Sud Quercy (France). Les Cahiers de l'Institut Catholique de Lyon $14,125-134$.

Damborenea, S.E., 2000. Hispanic corridor: its evolution and the biogeography of bivalve molluscs. GeoResearch Forum 6, 369-380.

Dépêche, F., 1985. Lias supérieur, Dogger, Malm. In: Oertli, H., (Ed.), Atlas des Ostracodes de France. Bulletin du Centre de Recherches d'Exploitation Production Elf Aquitaine, Mémoire 9, 119-145.

Dommergues, J.L., 1979. Le Carixien bourguignon: biostratigraphie, paléogéographie approches paléontologiques et sedimentologiques. Thèse 3 cycle. Université de Dijon, France, pp. 1-195

Dommergues, J.L., 1982. Le provincialisme des Ammonites boréales au Lias moyen; une crise faunique sous contrôle paléobiogéographique. Bulletin de la Société Géologique de France 7 (5-6), 1047-1051.

Dommergues, J.L., 1987. L évolution chez les Ammonitina du Lias moyen (Carixien, Domérien basal) en Europe occidentale. Documents des Laboratoires de Géologie de la Faculté des Sciences de Lyon 98, 1-297.

Dommergues, J.L., Mouterde, R., 1980. Modalités d'installation et d'évolution des Harpoceratines (Ammonitina) au Domérien inférieur dans le sud-ouest de l'Europe (France, Portugal). Geobios Lyon 13, 3.

Dommergues, J.L., Mouterde, R., 1987. The endemic trends of Liassic ammonite faunas of Portugal as the result of the opening up of a narrow epicontinental basin. Palaeogeography, Palaeoclimatology, Palaeoecology, Amsterdam 58, 129-137.

Dommergues, J.L., Meister, C., 1990. Les faunes d'ammonites liasiques de l'Austro alpin moyen dans les Alpes Rhétiques italiennes (Région de Livigno); biostratigraphie et implications paléogéographiques. Revues de Paléobiologie du Muséum Genève 9, 291-307.

Dommergues, J.L., Meister, C., 1991. Area of mixed marine faunas between two major palaeogeographical realms, exemplified by the
Early Jurassic late Sinemurian and Pliensbachian ammonites in the Alps. Palaeogeography, Palaeoclimatology, Palaeoecology 86 (3-4), 265-282.

Dommergues, J.L., Meister, C., 1992. Late Sinemurian and Early Carixian ammonites in Europe with cladistic analysis of sutural characters. Neues Jahrbuch für Geologie und Paläontologie Monatshefte 185, 211-237.

Dommergues, J.L., Meister, C., Mouterde, R., 1997. Pliensbachien. In: Cariou, E., Hantzpergue, P., Groupe François d'études du Jurassique (Eds.), Biostratigraphie du Jurassique ouest-européen et méditerranéen: zonation parallèles et distribution des invertébrés et microfossiles. Bulletin du Centre Recherche, Elf Exploration, pp. 15-23.

Donovan, D.T., 1967. The geographical distribution of Lower Jurassic ammonites in Europe and adjacent areas. In: Adams, C.G., Ager, D.V. (Eds.), Aspects of Tethyan Biogeography, vol. 7. Systematic Association Publication, London, pp. 111-134.

Donze, P., 1985. Lias Inférieur et Moyen. In: Oertli, H. (Ed.), Atlas des Ostracodes de France. Bulletin du Centre de Recherché Exploitation-Production Elf-Aquitaine Memoire Bordeaux, vol. 9, pp. 101-117.

Drexler, E., 1958. Foraminiferen und Ostracoden aus dem Lias von Siebeldingen Pfalz. Geologische Jahrbuch, Hannover 75, 475-554.

Dreyer, E., 1967. Mikrofossilem des Rät und Lias von SWBrandenburg. Geologische Jahrbuch, Hannover 1, 491-531.

Elmi, S., Alméras, Y., Ameur, M., Atrops, F., Benhamou, M., Moulan, G., 1982. La dislocation des plates-formes carbonatées liasiques en Méditerranée occidentale et les implications sur les enchantes fauniques. Bulletin de la Société Géologique de France 7 (24), 1007-1016.

Elmi, S., Atrops, F., Mangold, C., 1974. Les zones d'ammonites du Domérien-Toarcien. Documents des Laboratoires de Géologie de la Faculté des Sciences de Lyon 61, 1-83.

Enay, R., 1980. Paléobiogéographie et Ammonites jurassiques: "Rythmes fauniques" et variations du niveau marin; voies d'échanges, migrations et domaines biogéographiques. In: Livre Jubilaire de la Société Géologique de France, (1830-1980). Mémoires historique série de la Société Géologique de France, Paris 10, 261-281.

Enay, R., Mangold, C., 1982. Dynamique biogéographique et évolution des faunes d'ammonites du Jurassique. Bulletin de la Société Géologique de France, Paris 7 (24) 5-6, 1025-1046.

Espitalié, J., Marquis, F., Sage, L., Barsony, I., 1987. Géochemie organique du bassin de Paris. Revue de l' Institut français de Pétrole, Paris 42, 271-302.

Exton, J., 1979. Pliensbachian and Toarcian microfaunas of Zambujal, Portugal. Systematic Paleontology. Geological Paper Carleton University 79 (1), 1-104.

Exton, J., Gradstein, F.M. 1984. Early Jurassic stratigraphy and micropaleontology of the Grand Banks and Portugal. In: Westerman, G.E.C. (Ed.), Jurassic and Cretaceous biochronology and biogeography of North America. Special Paper of Geological Association, pp.13-28.

Faugères, J.C., Mouterde, R., 1980. Affinité des faunes dans le Lias sud rifain (Maroc); précisions sur l'évolution des paléo océans atlantique et mésogéen (abstract). 26th International Geological Congress Paris, Colloquium C5, pp. 1-288.

Fawcett, P.J., Barron, E.J., Robinson, V.D., Katz, B.J., 1994. The climatic evolution of India and Australia from the Late Permian to mid-Jurassic: a comparison of climate model results with the geologic record. In: Klein, G.D. (Ed.), Pangea: Paleoclimate, 
Tectonics, and Sedimentation during Accretion, Zenith, and Breakup of a Super continent. Geological Society of America Special Paper 288, 139-157.

Field, R.A., 1966. Species of the family Cytherellidae (Ostracoda) from the Lower Lias of south Dorset, England. Senckenbergiana Lethaea 47, 87-105.

Fischer, W., 1961a. Neue Arten Ostracoden-Gattung Polycope SARS (1865) aus dem Oberen Lias (Württenberg). Neues Jahrbuch für Geologie und Paläontologie Monatshefte 8, 497-501.

Fischer, W., 1961b. Über die Lias/Dogger-Grenze in Süddeutschland. Neues Jahrbuch für Geologie und Paläontologie Monatshefte 8, 394-400.

Fischer, W., 1961c. Über die Bildungsbedingungen der Posidonienschiefer in Süddeutschland. Neues Jahrbuch für Geologie und Paläontologie Monatshefte 8, 326-340.

Fischer, W., 1962. Ostracoden der Gattungen Monoceratina Roth, Cytheropteron G.O. Sars und andere im Lias Zeta Schwabens. Neues Jahrbuch für Geologie und Paläontologie Abhandlungen, Stuttgart 114, 333-345.

Fleet, AJ., Clayton, C.J., Jenkyns, H.C., Parkinson, D.N., 1987. Liassic source-rock deposition in Western Europe. In: Brooks, J., Glennie, K. (Eds.), Petroleum Geology of Northwest Europe. Graham and Trotman, London, pp. 59-70.

Frakes, L.A., 1979. Climates throughout Geologic Time. Elsevier, Amsterdam, p. 310.

Frakes, L.A., Francis, J.E., 1988. A guide to Phanerozoic cold polar climates from high-latitude ice rafting in the Cretaceous. Nature, London 333, 547-549.

Frakes, L.A., Francis, J.E., Syktus, J.I., 1992. Climate modes of the Phanerozoic. Cambridge University Press, p. 274.

Gabilly, J., 1976. Le Toarcien à Thouars et dans le centre-ouest de la France. Éditions du. CNRS, Paris, pp. 1-217.

Garcia Joral, F., Goy, A., 1984. Características de la fauna de braquiópodos del Toarciense superior en el Sector Central de la Cordillera Ibérica (Noroeste de España). Estudios Geológicos, Madrid 40, 55-59.

Gibbs, M.T., Rees, P.M., Kutzbach, J.E., Ziegler, A.M., Behling, P., Rowley, D.B., 2002. Simulations of Permian climate and comparisons with climate-sensitive sediments. Journal of Geology $110,33-55$.

Gómez, J.J., Goy, A., 2002. The lower Jurassic cycles and palaeogeographical evolution of the central portion of the Tberian platform (Eastern Spain). In: Martire, L. (Ed.), 6th International Symposium on the Jurassic System, Lisbon, pp. 76-77.

Goy, A., 1974. El Lias de la mitad norte de la Rama Castellana de la Cordillera Ibérica. Unpub. PhD thesis. Facultad Ciencias Geológicas, Universidad Complutense de Madrid, pp. 940

Goy A., Martínez, G., 1990. Biozonación del Toarciense en el área de La Almunia de Doña Godina-Ricla (Sector Central de la Cordillera Ibérica). Cuadernos de Geología Ibérica 14, 9-44

Goy, A., Comas-Rengifo, M.J., Garcia-Joral, F., 1984. The Liassic Brachiopods of the Cordillera Ibérica (Spain). Stratigraphic distribution and Biozonation. In: Michelsen, O., Zeiss, A. (Eds.), International Symposium on Jurassic Stratigraphy, Erlangen, Berlin, pp. 2-9.

Goy, A., Jiménez, A.P., Martínez, G., Rivas, P., 1988. Difficulties in correlating the ammonite successions of the Iberian and Betic cordilleras. In: Rocha, R.B., Soares, A.F. (Eds.), 2nd International Symposium on Jurassic Stratigraphy, Lisbon, pp. 155-178.

Gramann, F., 1962. Extremitätenfunde an Rassischen Bairdien (Ostracoda). Palaeontologische Zeitschrift 36, 28-32.

Gramann, F., 1963. Liasina n. gen. (Ostracoda) aus dem deutchen Lias. Geologishe Jahrbuch 6-74.
Gründel, J., 1964. Zür Gattung Healdia (Ostracoda) und zu einingen verwandten Formen aus dem unteren Jura. Geologie, Berlin 13 (4), 456-477.

Gründel, J., 1970. Die Ausbildung der Muskelnarben an liassischen Vertretern der Healdiidae (Ostrac.). Freiberger Forschungshefte $\mathbf{H}$ (C), Leipzig 256, 47-63.

Hallam, A., 1971. Mesozoic geology and the opening of the North Atlantic. Journal of Geology, London 79, 129-157.

Hallam, A., 1975. Jurassic Environments. Cambridge University Press, p. 269.

Hallam, A., 1978. Eustatic cycles in the Jurassic. Palaeogeography, Palaeoclimatology, Palaeoclimatology, Amsterdam 23, 1-32.

Hallam, A., 1981. A revised sea-level curve for the Early Jurassic. Journal of the Geological Society, London 138 (6), 735-743.

Hallam, A., 1984. Distribution of fossil marine invertebrate in relation to climate. In: Brenchley, P.J. (Ed.), Fossil and Climate. Wiley, London, pp. 107-125.

Hallam, A., 1985. A review of Mesozoic climates. Journal of Geology, London 142, 433-435.

Hallam, A., 1987. Mesozoic marine organic-rich shales. In: Brooks, J., Fleet, A. (Eds.), Marine Petroleum Source Rocks, Special Publication of the Geological Society of London, vol. 26, pp. 251-261.

Hallam, A., 1994. Jurassic climates as inferred from the sedimentary and fossil record. In: Allen, J.R.L., Hoskins, B.I., Sellwood, B.W., Spicer, R.A., Valdes, P.J. (Eds.), Paleoclimates and their modelling with special reference of the Mesozoic era. Chapman and Hall, London, pp. 79-88.

Hames, W.E., McHone, J.G., Ruppel, C., Renne, P., 2002. The Central Atlantic Magmatic Province: Insights from Fragments of Pangea. American Geophysics Union Monograph 136, 1-267.

Haq, B.U., Hardenbold, J.L., Vail, P.R., 1987. Chronology of fluctuating sea levels since the Triassic. Science, Washington $235,1156-1167$.

Haq, B.U., Hardenbold, J.L., Vail, P.R., 1988. Mesozoic and Cainozoic chronostratigraphy and cycles of sea-level changes. Sea-Level changes, Society of Economic Palaeontologist and Mineralogist, vol. 42. Special Publication, Tulsa, Oklahoma, pp. 71-108.

Hardenbol, J., Thierry, J., Farley, M.B., Jacquin, T., De Graciansky, P.C., Vail, P.R., 1998. Mesozoic and Cenozoic sequence chronostratigraphic framework of European basins. In: De Graciansky, P.-C., Hardenbol, J., Jacquin, T., Vail, P.R. (Eds.), Mesozoic and Cainozoic sequence stratigraphy of European basins. SEPM (Society for Sedimentary Geology Special Publications), vol. 60, pp. 343-360.

Harloff, J., 1993. Ostracoden des Unter-Pliensbachiums in BadenWürttemberg. Stuttgarter Beiträge zur Naturkunde. Serie B (Geologie und Paläontologie) 191, 1-214.

Harloff, J., Jäger, J., 1994. Ostracoden aus dem Lias der Kalkalpen Bayern und Nordtirols. Stuttgarter Beiträge zur Naturkunde. Serie B (Geologie und Paläontologie) 205, 1-63.

Herrig, E., 1969a. Ostracoden aus dem Ober-Domèrien von Grimmen westlich Griefswald (Teil I). Geologie, Berlin 18, 446-471.

Herrig, E., 1969b. Ostracoden aus dem Ober-Domèrien von Grimmen westlich Griefswald (Teil II). Geologie, Berlin 18, 1072-1101.

Herrig, E., 1979a. Die Gattung Bairdia (Ostracoda, Crustacea) im Lias von Thüringen. Zeitschrift für Geologische Wissenschaften, Berlin 7 (5), 641-661.

Herrig, E., 1979b. Ostrakoden aus dem Lias von Thüringen. Die Gattungen Bairdia (Teil II), Fabalacypris and Bairdiacypris. Zeitschrift für Geologische Wissenschaften, Berlin 7 (6), 763-782. 
Herrig, E., 1980. Ostrakoden der Gattungen Ledahia and Pseudohealdia (Familie: Healdiidae Harlton) aus dem Lias von Thüringen. Zeitschrift für Geologische Wissenschaften, Berlin 8 (12), 1539-1551.

Herrig, E., 1981a. Die Gattung Ogmoconcha Triebel, 1941 (Ostracoda) im Lias von Thüringen. Zeitschrift für Geologische Wissenschaften, Berlin 9 (2), 207-219.

Herrig, E., 1981b. Die Gattung Ogmoconchella-Arten (Ostracoda) im Lias von Thüringen. Zeitschrift für Geologische Wissenschaften, Berlin 9 (5), 561-579.

Herrig, E., 1981c. Die polycopiden Ostrakoden aus dem thüringischen Lias. Zeitschrift für Geologische Wissenschaften, Berlin 9 (6), 675-696.

Herrig, E., 1982a. Ostrakoden aus dem Lias von Thüringen. Die Familien Progonocytheridae, Cytherettidae und Brachycytheridae. Zeitschrift für Geologische Wissenschaften 10, 1449-1461.

Herrig, E., 1982b. Ostrakoden aus dem Lias von Thüringen. Die Familien Trachyleberididae, Paradoxostomatidae, Cytherellidae sowie Nachtrag zu den Paracyprididae. Zeitschrift für Geologische Wissenschaften 10, 231-243.

Herrig, E., 1985. Zur Taxonomie und Evolution der Gattung Kinkelinella Martin, 1960 (Ostracoda) im Unteren Jura von Mittel- und Nordwesteuropa. Zeitschrift für Geologische Wissenschaften, Berlin 13 (6), 715-723.

Herrig, E., Richter, H., 1990. Zur Entwicklung der Cytheropterinae (Ostracoda Crustacea) im oberen Lias von Mitteleuropa. Neues Jahrbuch für Geologie und Paläontologie Abhandlungen, Stuttgart 180 (2), 239-257.

Hesselbo, S.P., Gröcke, D.R., Jenkyns, H.C., Bjerrum, C.J., Farrimond, P., Morgans-Bell, H.S., Green, O.R., 2000. Massive dissociation of gas hydrates during a Jurassic oceanic anoxic event. Nature 406, 392-395.

Hesselbo, S.P., Robinson, S.A., Surlyk, F., 2004. Sea-level change and facies development across potential Triassic-Jurassic boundary horizons, SW Britain. Journal of the Geological Society 161 (3), $365-379$.

Issler, A., 1908. Beiträge zur Stratigraphie und Mikrofauna des Lias in Schwaben. Paleontographica, Stuttgart 55, 104 pp.

Jenkyns, H.C., 1985. The early Toarcian and Cenomanian-Turonian anoxic events in Europe: comparisons and contrast. Geologische Rundschen, Frankfurt am Main 74, 505-518.

Jenkyns, H.C., 1988. The early Toarcian (Jurassic) anoxic event: stratigraphic, sedimentary and geochemical evidence. American Journal of Science, Connecticut 288, 101-151.

Jenkyns, H.C., 2003. Evidence for rapid climate change in the Mesozoic-Palaeogene greenhouse world. Philosophical Transaction of the Royal Society of London 361, 185-1916.

Jenkyns, H.C., Clayton, C.J., 1986. Black shales and carbon isotopes in pelagic sediments from the Tethyan Lower Jurassic. Sedimentology, Oxford 33, 87-106.

Jenkyns, H.C., Clayton, C.J., 1997. Lower Jurassic epicontinental carbonates and mudstones from England and Wales: chemostratigraphic signals and the early Toarcian anoxic event. Sedimentology $44,687-706$.

Jenkyns, H.C., Jones, C.E., Gröcke, D.R., Hesselbo, S.P., Parkinson, D.S., 2002. Chemostratigraphy of the Jurassic System: applications, limitations and implications for palaeoceanography. Journal of Geology of London 159, 351-378.

Jones, T.R., 1872. On some Bivalve Entomostraca from the Lias (Infralias) of Yorkshire. In: Blake, J.F. (Ed.), On the Infralias in Yorkshire. Quarter Journal of Geology Society of London, vol. 28/1, pp. 146-147. London.
Klingler, W., 1962. Lias Deutschland. In: Klingler, W. (Ed.), Arbeitskreis deutcher Mikropäleontologen (Hgrs). Leitfossilien der Mikropaläontologie, Berlin, pp. 73-122.

Klingler, W., Neuweiler, F, 1959. Leitende Ostracoden aus dem deutschen Lias. Geologische Jahrbuch A 76, 373-410.

Knauff, W., 1954. Paläontologisch stratigraphische Untersuchungen an Mikrofossilen aus dem Lias Delta vor the Schwäbischen Alb. Dissertation, Universität der Tübingen, Deutschland pp. 1-142.

Knitter, H., 1983. Biostratigraphische Untersuchungen mit Ostracoden im Toarcien Süddentschlands. Facies, Erlangen 8, 213-262.

Knitter, H., 1984. Ostracod biostratigraphy of the Upper Toarcian in Southern Germany. International Symposium on Jurassic Stratigraphy, Lisbon, Portugal 252-258.

Knitter, H., Ohmert, W., 1983. Das Toarcium an der Schwärz bei Badenweiler (Oberrheingebiet S. Freiburg). Jahrbuch der Geologischen Landesamt Baden-Württemberg, Freiburg 24, 233-281.

Knitter, H., Riegraf, W., 1984. Biostratigraphie (Cephalopoden, Ostracoden ) des Oberen Toarcium von Blumberg Achdorf, Wutachs und Weilheim/Teck (Baden-Württemberg). Jahrbuch der Geologischen Landesamt Baden-Württemberg, Freiburg 26, 57-97.

Kocurek, G., Dott Jr., R.H., 1983. Jurassic paleogeography of the central and southern Rocky Mountains region. In: Reynolds, M. W., Dolly, E.D. (Eds.), Mesozoic paleogeography of the WestCentral United States. Rocky Mountain paleogeography symposium, Denver, Rocky Mountain Section. Society of Economic Palaeontologists and Mineralogists, vol. 2, pp. 101-116.

Küspert, W., 1982. Environmental change during oil shale deposition as deduced from stable isotope ratios. In: Einsele, S., Seilacher, A. (Eds.), Cyclic and Event Stratification. Springer, New York, pp. 482-501.

Kutzbach, J.E., 1985. Modelling of paleoclimates. Advances in Geophysics, vol. 28A. Academic Press, London, pp. 159-196.

Kutzbach, J.E., Gallimore, R.G., 1989. Pangaean climates: megamonsoons of the megacontinent. Journal of Geophysical Research 94, 3341-3357.

Kutzbach, J.E., Guetter, P.J., Washington, W.M., 1990. Simulated circulation of an idealized ocean for Pangaean time. Paleoceanography $5,299-317$.

Laubscher, H., Bernoulli, D., 1977. Mediterranean and Tethys. In: Nairn, A.E.M., Kanes, W.H., Stehli, H. (Eds.), The Ocean Basins and Margins. Plenum Publication Company, New York, pp. 1-28.

Lethiers, F., Crasquin-Soleau, S., 1995. Distribution des ostracodes et paléontologie au Carbonifère terminal Permien, Geobios, Mémoire spéciale $18,257-272$.

Liu, Ch., Heinze, M., Fürsich, F.T., 1998. Bivalve provinces in the Proto Atlantic and along the southern margin of the Tethys. Palaeogeography, Palaeoclimatolology, Palaeoecolology, Amsterdam 137, 127-151.

Lord, A., 1971a. The ostracod genera Ogmoconcha and Procytheridea in the Lower Jurassic. Danmarks Geologiske Undersogelse 21, 319-336.

Lord, A., 1971b. Revision of some Lower Lias Ostracoda from Yorkshire. Palaeontology, London 14, 642-665.

Lord, A., 1972. Wicherella and Gramannella, two new genera of Lower Jurassic from England. Palaeontology, London 15 (2), 187-196.

Lord, A., 1974a. Ostracods from the Domerian and Toarcian of England. Paleontology 17, 599-622.

Lord, A., 1974b. On Bairdia aselfingenensis Lord and Moorley sp. nov. Stereo Atlas of Ostracod Shells 2 (2), 5-8. 
Lord, A., 1974c. On Ogmoconcha ambo Lord and Moorley sp. nov. Stereo Atlas of Ostracod Shells 2 (3), 9-16.

Lord, A., 1978. The Jurassic. Part. 1 (Hettangian-Toarcian). In: Bate, R., Robinson, E. (Eds.), A Stratigraphic Index of British Ostracoda, vol. 8. Seel House Press, London, pp. 189-212.

Lord, A., 1988. Ostracoda of the Early Jurassic Tethyan Ocean. In: Hanai, T., Ikeya, N., Ishizaki, K. (Eds.), Biology of Ostracoda: Its Fundamental and Applications. Proceeding of the Ninth International Symposium on Ostracoda, Shizouoka, Japan, vol. 11. Developments in Paleontology and Stratigraphy, Elsevier, pp. 855-867.

Lord, A., Bown, P., 1987. Mesozoic and Cenozoic stratigraphical micropalaeontology of the Dorset Coast and Isle of Wight, Southern England. Field guide for the Twentieth European Micropaleontological Colloquium. British Micropalaeontological Society Field Guide 1, 1-233.

Lord, A., Moorley, A., 1974. On Ogmoconcha ambo sp. nov. Amsterdam. Stereo-Atlas of ostracod shells 2, 9-16.

Magné, J., Malmoustier, G., 1961. Quelques espèces nouvelles d' Ostracodes du Toarcien de Thouars (Deux-Sèvres. In: Cousin, N., Espatilier, J., Sigal, J., Apostolescu, V. (Eds.), Colloque sur le Lias français. Mémoire Bureau Recherche Géologiques Minières, vol. 4, pp. 399-405.

Magné, J., Obert, D., 1966. Niveaux a microfaunes dans le Lias de la région d'Arbois (Jura). Revue de Micropalèontologie 8 (4), 265-273.

Magné, J., Séronie-Vivien, R.M., Malmoustier, G., 1961. Le Toarcien de Thouars. In: Cousin, N., Espatilier, J., Sigal, J., Apostolescu, V. (Eds.), Colloque sur le Lias français. Mémoire Bureau Recherche Géologiques Minières, vol. 4, pp. 357-397.

Malz, H., 1961. Erörterung der taxionalischen Fassung der Progonocyterinae (Ostracoda). Senckbergiana Lethaea 42 (1/2), 175-179.

Malz, H., 1966. Zur Kenntnis Ostracoden-Arten der Gattungen Kinkelinella und Praeschuleridea. Senckbergiana Lethaea 47 (4), $385-404$

Malz, H., 1971. Zur Taxonomie "Glattschaliger" Lias Ostracoden. Senckbergiana Lethaea 52, 433-455.

Malz, H., 1975. Eine Entwicklungsreihe "vallater" Ogmoconchen (Ostracoda) im S-deutschen Lias. Senckbergiana lethaea 55 (6), $485-505$

Malz, H., Lord, A., 1976. Gammanacythere n.g. (Ostracoda) and its occurrence I the Lower Jurassic of N.W. Europe. Senckbergiana Lethaea 57, 249-263.

Malz, H., Nagy, J., 1989. Lower Jurassic ostracods from North Sea wells in the Norwegian Sector. In: Malz, H. (Ed.), Contributions to the European Ostracodologist Meeting, 1, Courier Forschungsinstitut Senckenberg, Frankfurt am Main, 11, 61-75.

Martin, G.P.R., 1960. Mikrofauna. In: Die Zone des Dactylioceras tenuicostatum (Toarcien, Lias) in NW und SW-Deutschland. In: Hoffmann, K., Martin, G.P.R (Eds.), Paleontologisches Zeitschrift, Stuttgart, 2, 103-149.

Marzoli, A., Renne, P.R., Piccirillo, E.M., Ernesto, M., Bellieni, G., De Min, A., 1999. Extensive 200 million-year-old continental flood basalts of the central atlantic magmatic province. Science 284, 616-618.

Maupin, C., 1978. Deux ostracodes nouveaux du Toarcien de Vendée (France). Geobios 11, 107-111.

McArthur, J.M., Donovan, D.T., Thirlwall, M.F., Fouke, B.W., Mattey, D., 2000. Strontium isotope profile of the early Toarcian (Jurassic) oceanic anoxic event, duration of ammonite biozones, and belemnite palaeotemperatures. Earth Planetary Scientific Letter $179,269-285$
McHone, J.G., 1996. Broad-terrain Jurassic flood basalts across northeastern North America. Geology 24, 319-322.

McHone, J.G., 2000. Non-plume magmatism and tectonics during the opening of the central Atlantic Ocean. Tectonophysics 316, $287-296$

McHone, J.G., 2002. Volatile emissions of Central Atlantic magmatic province basalts: mass assumptions and environmental consequences. In: Hames, W.E., McHone, J.G., Renne, P.R., Ruppel, C. (Eds.), The Central Atlantic Magmatic Province: American Geophysical Union, Geophysical Monograph, vol. 136, pp. 241-254.

McKenzie, K.G., 1973. Cenozoic ostracoda. In: Hallam, A. (Ed.), Atlas of Palaeobiogeography. Elsevier, Amsterdam, pp. 447-487.

Meister, C., Stamfly, G., 2000. Les ammonites du Lias moyen (Pliensbachian) de la Neotethys et des confins, compositions fauniques, affinités paléogéographiques et biodiversité. Revue du Paléobiologie, Genève 19 (1), 227-292.

Mégnien, C., 1980. Synthèse géologique du Bassin de Paris. Mémoire du Bureau de Recherches Géologiques et Minières $101,1-466$.

Michelsen, O., 1975. Lower Jurassic biostratigraphy and ostracods of the Danish Embayment. Danmarks Geologiske Undersøgelse, Kopenhavn 104 (2), 1-289.

Mouterde, R., 1953. Études sur le Lias et Bajocien des bordures nord et nord-est du Massif central français. Monographies régionales 1951-53. Bulletin du Service Carte Géologique du France 1-236.

Mouterde, R., Rocha, R.B., Ruget, C., Tintant, H., 1979. Faciès, biostratigraphie et palèogèographie du jurassique portugais. Ciencias de la Terra, Lisbon 5, 29-52.

Oertli, H.J., Grosdidier, E., 1961. Ostracodes de quelques sondages du Lias du Bassin de Paris. Le Toarcien de Thouars. In: Cousin, N., Espatilier, J., Sigal, J., Apostolescu, V. (Eds.), Colloque sur le Lias français Mémoire du Bureau de Recherche Géologiques et Minières, vol. 4, pp. 459-461.

Ohm, H.H., 1986. Ostrakoden. In: Fischer, R., Jager, M., Konstantinopoulu, A., Kristan-Tollmann, E., Luppold, F.W., Ohm, H.H. (Eds.), Paläontologie einer epikontinentalen Lias-Schichtfolge: Oberes Sinemurium bis Oberes Domerium von Empelde bei Hannover. Facies, Erlangen, vol. 15, pp. 53-176.

Park, S.M., 1984. On Ogmocncha contractula Park sp. Nov. Sterep Atlas of Ostracod Shells, London, 11/14, 67-70.

Parrish, J.T., Curtis, R.L., 1982. Atmospheric circulation, upwelling and organic rich rocks in the Mesozoic and Cenozoic Eras. Palaeogeography, Palaeoclimatolology, Palaeoecolology, Amsterdam 40, 31-66.

Parrish, J.T., Ziegler, A.M., Scotese, C.R., 1982. Rainfall patterns and the distribution of coals and evaporites in the Mesozoic and Cenozoic. Palaeogeography, Palaeoclimatolology, Palaeoecolology, Amsterdam 40, 67-101.

Phelps, M.C., 1985. A refined ammonite biostratigraphy for the middle and upper Carixian (ibex and davoei zones, Lower Jurassic) in North-West Europe and stratigraphical details of the CarixianDomerian boundary. Geobios, Lyon 18, 321-361.

Pietrzenuk, T., 1961. Zur Mikrofauna einiger Lias vorkommen in der Deutchen Demokratischen Republik. Freiberger Forschunghelfe, H(C) 113, 1-129.

Plumhoff, F., 1963. Die Ostracoden des Oberaalenium und tiefen Unterbajocium (Jura) des Gifhorner Troges, Nordwestdeutschlands. Abhandlungen der Senckenbergischen Naturforschenden Gesellschaft, Band 503, pp. 100.

Quenstedt, F.A., 1967. Der Jura. VI, Tübingen, Laup and Siebeck, pp. 1-842. 
Rees, P.M., Ziegler, A.M., Valdes, P.J., 2000. Jurassic phytogeography and climates: new data and model comparisons. In: Huber, B.T., Macleod, K.G., Wing, S.L. (Eds.), Warm climates in Earth history. Cambridge University Press, pp. 297-318.

Richter, H., 1987. Die Mikrofauna des Unteren Toarcium der Nordschweiz. Neues Jahrbuch für Geologie und Paläontologie Abhandlungen 176, 137-155.

Riegraf, W., 1984. Neue Ostracoden-Arten aus dem Oberem Pliensbachium und Unteren Toarcium Südwestdeutschland und Südfrankreichs. Stuttgarter Beitrage zur Naturkunde, Serie B 104, 1-19.

Riegraf, W., 1985. Microfauna, Biostratigraphie und Fazies im Unteren Toarcian Südwestdeutschland und Vergleiche mit benachbarten Gebieten. Tübinger Mikropalaontologische Mitteilungen 3, $1-232$.

Riegraf, W., Werner, G., Löcher, F., 1984. Der Posidonienschiefer. Biostratigraphie, Fauna und Fazies des südwestdeutschen Untertoarciums (Lias ع), Enke, Stuttgart 1-195.

Robertson, A.H.F., Ogg, J.G., 1986. Palaeoceanographic setting of the Callovian of the North Atlantic. In: Summerhayes, C.P., Shackleton, N.J. (Eds.), North Atlantic Palaeoceanography, vol. 21. Special Publications of the Geological Society of London, pp. 283-298.

Röhl, H., Schmid-Röhl, A., Oschmann, W., Frimmel, A., Schwark, L., 2001. The Posidonian Shale (Lower Toarcian) of SW-Germany: an oxygen depleted ecosystem controlled by sea level and palaeoclimate. Palaeogeography, Palaeoclimatology, Palaeoecology, Amsterdam 165, 27-52.

Rosales, I., Quesada, S., Robles, S., 2004. Paleotemperature variations of Early Jurassic seawater recorded in geochemical trends of belemnites from the Basque-Cantabrian basin, northern Spain. Palaeogeography. Palaeoclimatology Palaeoecology, Amsterdam 203, 253-275.

Ruiz-Ortiz, P.A., Bosence, D.W.J., Rey, J., Nieto, L.M., Castro, J.M., Molina, J.M., 2004. Tectonic control of facies architecture, sequence stratigraphy and drowning of a Liassic carbonate platform (Betic Cordillera, Southern Spain). Basin Research 16 (2), 235-257.

Sælen, G., Tyson, R.V., Telnæs, N., Talbot, M.R., 2000. Contrasting water mass conditions during deposition of the Whitby Mudstone (Lower Jurassic) and Kimmeridge Clay (Upper Jurassic) Formations UK. Palaeogeography, Palaeoclimatology, Palaeoecology, Amsterdam 163, 163-196.

Sandberg, P.A., 1964. The ostracode genus Cyprideis in the Americas. Stockholm Contribution Geology 12, 178.

Schmid-Röhl, A., Röhl, H.J., Oschmann, W., Frimmel, A., Schwark, L., 2002. Palaeoenvironmental reconstruction of Lower Toarcian epicontinental black shales (Posidonia Shale, SW Germany): Global versus regional control. Geobios, Lyon 35, 13-20.

Schouten, S., Kaam-Peters, M.E., Rijpstra, I., Schoell, M., Sinnighe Damste, J.S., 2000. Effects of an oceanic anoxic event on the stable carbon isotopic composition of early Toarcian carbon. American Journal of Science 300, 1-22.

Schram, F.R., 1986. Crustacea. Oxford University Press, pp. 1-206.

Schwager, 1866. Foraminiferen. In: Waagen, W. (Ed.), Über die Zone des Ammonites sowerbyi, Geogn Paláontologie Beitrage, Hannover, 1, pp. 508-665.

Scotese, C.R. 2002. Plate Tectonic animation, Jurassic to Quaternary, http://www.scotese.com (PALEOMAP website).

Scotese, C.R., Summerhayes, C.P., 1986. Computer model of Paleoclimate predict coastal upwelling in the Mesozoic and Cenozoic. Geobyte $28-42$.

Sellwood, B.W., Valdes, P.J., Price, G.D., 2000. Geological evaluation of multiple GCM simulations of Late Jurassic paleoclimate
Palaeogeography Palaeoclimatolology, Palaeoecology, Amsterdam 156, 147-160.

Sivhed, U., 1980. Lower Jurassic ostracods and stratigraphy of western Skåne, southern Sweden. Sveriges Geologiska Undersokkning, C $50,1-85$.

Stampfli, G.M., Marcoux, J., Baud, A., 1991. Tethyan margins in space and time. Palaeogeography, Palaeoclimatolology, Palaeoecolology, Amsterdam 87, 373-410.

Stampfli, G.M., Mosar, J., Marquer, D., Marchant, R., Baudin, T., Borel, G., 1998. Subduction and obduction processes in the Swiss Alps. Tectonophysics 296, 1159-1204.

Thierry, J., 1988. Structure and palaeogeography of the western Tethys during the Jurassic: test based on ammonite palaeobiogeography. In: Audley-Charles, M.G., Hallam, A. (Eds.), Gondwana and Tethys. Geological Society of London, vol. 37, pp. 225-234.

Triebel, E., 1941. Zur Morphologie und Ökologie der fossilen Ostrakoden. Mit Beschreibung iniger neuer Gattungen und Arten. Senckbergiana. 23/4, 294-400.

Triebel, E., Bartenstein, H., 1938. Die Ostracoden des deutschen Juras. Monoceratina-Arten aus dem Lias. Senckbergiana lethaea 20, 502-518.

Triebel, E., Klingler, W., 1969. Neue Ostracoden-Gattungen aus dem deutschen Lias. Geologie, Berlin 76, 335-372.

Tröster, J., 1987. Biostratigraphie des Obertoarcium und der Toarcium/ Aalenium-Grenze der Bohrungen Weiach Beznau, Riuiken und Schafishheim (Nordschweiz). Eclogae Geologicae Helvetiae, Basel 80 (2), 431-449.

Tyson, R.V., Pearson, T.H., 1991. Modern and Ancient Continental Shelf Anoxia. Special Publication of the Geological Society of London 58, 470 .

Urlichs, M., 1977. Stratigraphy, Ammonite Fauna and some Ostracods of the Upper Pliensbachian at the Type Locality (Lias SWGermany). Stuttgarter Beitrage Naturkunde B 28, 1-13.

Vail, P.R., Mitchum, R.M., Thompson, S., Todd, R.G., Sangree, J.B., Widmier, J.M., Bubb, J.N., Hatlelid, W.G., 1977. Seismic stratigraphy and global changes of sea-level. Memoirs of the American Association of Petrologist and Geologists 26, 49-212.

Vakhrameev, V.A., 1964. Jurassic floras of the Indo-European and Siberian botanical-geographical regions. Publications de l'Institut Royal Grand-Ducal de Luxembourg, section des sciences naturelles et mathematiques Luxembourg 411-421.

Vakhrameev, V.A., 1991. Jurassic and Cretaceous floras and climates of the Earth. Cambridge University Press, Cambridge, p. 318.

Van de Schootbrugge, B., McArthur, J.M., Bailey, T.R., Rosenthal, Y., Wright, J.D., Miller, K.G., 2005. Toarcian oceanic anoxic event: an assessment of global causes using belemnite $\mathrm{C}$ isotope records. Paleoceanography 20, 2-10.

Van Morkhoven, F.P.C.M., 1962-1963. Post-Paleozoic Ostracoda. Their morphology, taxonomy and economic use, vol. 1. Elsevier, Amsterdam, pp. 1-478.

Vannier, J.M.C., Siveter, D.J., Schallreuter, R.E.L., 1989. The composition and palaeogeographical significance of the Ordovician ostracode faunas of Southern Britain, Baltoscandia, and IberoArmorica. Palaeontology 32, 163-222.

Vera, J.A., 1998. El Jurásico de la Cordillera Betica. Estado actual de conocimientos y problemas pendientes. Cuadernos de Geologia Ibérica 24, 17-42.

Viaud, J., 1963. Les ostracodes des principaux bassins liasiques français. Unpl. thesis. Paris.

Vöros, A., 1977. Provinciality of the Mediterranean Lower Jurassic brachiopod fauna: causes and plate-tectonic implications. Palaeogeography, Palaeoclimatolology, Palaeoecolology, Amsterdam 21 (1), 1-16. 
Whatley, R.C., 1988. Ostracods and palaeogeography. In: De Deckker, P., Colin, J.P., Peypouquet, J.P. (Eds.), Ostracoda in the Earth Sciences. Elsevier, Amsterdam, pp. 103-123.

Wienholz, E., 1958. Mikropaläontologische Ergebnisse aus dem Unter und Oberlias einiger Bohrungen in W-Mecklenburg. Zeitschrift angenwardte Geologie, Berlin-Ost, 4, pp. 1-435.

Wignall, P.B., Hallam, A., 1991. Biofacies, stratigraphic distribution and depositional models of British onshore Jurassic black shales. In: Tyson, R.V., Pearson, T.H. (Eds.), Modern and Ancient Continental Shelf Anoxia. Special Publication o the Geological Society of London, vol. 58, pp. 291-309.

Wignall, P.B., Meyers, K.J., 1990. Interpreting benthic oxygen levels in mudrocks: a new approach. Geology, Colorado 16, 452-455.

Winguth, A.M.E., Heinze, C., Kutzbach, J.E., Maier-Reimer, E., Mikolajewicz, U., Rowley, D.B., Rees, P.M., Ziegler, A.M., 2002. Simulated warm polar currents during the Middle Permian. Paleoceanography 17 (5), 1057.

Wood, A.M., Whatley, R.C., 1994. Northeastern Atlantic and Arctic faunal provinces based on the distribution of recent ostracod genera. The Holocenen 4, 174-192.

Ziegler, P.A., 1988. Post-Hercynian plate reorganization in the Tethys and Arctic-North Atlantic domains. In: Manspeizer, W. (Ed.), Triassic-Jurassic Rifting: Continental Break-Up and Origin of the Atlantic Ocean and Passive Margin. Elsevier, Amsterdam, Part B, pp. 711-755.

Ziegler, P.A., 1990. Geological Atlas of Western and Central Europe. Shell International Petrology. Maatschappi B.V. Geological Society Publishing House, Bath, pp. 1-239.
Ziegler, P.A., 1991. Palaeogeographic Atlas Project. University of Chicago, Department of the Geophysical Sciences. University of Bern, p. 191.

Ziegler, P.A., 1992. Geological Atlas of Western and Central Europe. Elsevier, Amsterdam, p. 130.

Ziegler, A.M., Hulver, M.L., Lottes, A.L., Schmactenberg, W.F., 1984. Uniformitarism and paleoclimates inferences from the distribution of carbonates rocks. In: Brenchley, P.J. (Ed.), Fossils and Climate. Wiley, Chichester, pp. 3-25.

Ziegler, A.M., Yao, J.M., Gyllenhaal, J., Rowley, E.D., Parrish, D.B., Nie, J.T., Bekker, S., Hulver, A., 1994. Early Mesozoic phytogeography and climate. In: Hoskins, J.R.L., Spicer, B.W., Valdes, R.A. (Eds.), Paleoclimates and their modelling; with special reference to the Mesozoic Era. Chapman and Hall, London, pp. 89-97.

Ziegler, A.M., Gibbs, M.T., Hulver, M.L., 1998. A mini-atlas of oceanic water masses in the Permian period. Proceedings of the Royal Society of Victoria 110 (1-2), 323-343.

Ziegler, P.A., Cloetingh, R., Guiraud, R., Stampfli, G.M., 2001. PerTethyan platform: dynamics of rifting and basin inversion. In: Cavazza, W., Robertson, A.H.F.R., Ziegler, P.A. (Eds.), Peritethyan rift/wrench basins and passive margines. IGCP 369. Bulletin du Muséum National de Histoire Naturelle, Paris. Peri-Tethys Mémoire, vol. 6, pp. 9-49.

Ziegler, A.M., Eshel, G., Rees, P.M., Rothfus, T.A., Rowley, D.B., Sunderlin, D., 2003. Tracing the tropics across land and sea: Permian to present. Lethaia $36,227-254$. 